\title{
Interplinian effusive activity at Popocatépetl volcano, Mexico: New insights into evolution and dynamics of the plumbing system
}

\author{
Martin Friedrich Mangler ${ }^{\star \alpha}, \beta, \gamma$, Julie Prytulak $\beta, \delta$, Guillem Gisbert ${ }^{\epsilon, \zeta}$, \\ Hugo Delgado-Granados ${ }^{\epsilon}$, Chiara Maria Petrone ${ }^{\alpha}$ \\ ${ }^{\alpha}$ Department of Earth Sciences, The Natural History Museum, Cromwell Road, SW7 5BD London, UK. \\ $\beta$ Department of Earth Science and Engineering, Imperial College London, SW7 2AZ, London, UK. \\ $\gamma$ School of Environmental Sciences, University of East Anglia, NR4 7JT, Norwich, UK. \\ ${ }^{\delta}$ Department of Earth Sciences, Durham University, DH1 3LE Durham, UK. \\ ${ }^{\epsilon}$ Insitituto de Geofísica, Universidad Autónoma de México, Ciudad Universitaria 04510 México, D.F., Mexico.

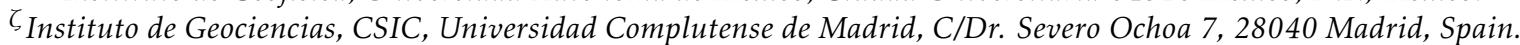

\begin{abstract}
Effusive eruptions dominate the eruptive record of many arc volcanoes and may hold crucial information about their plumbing systems, yet they are underrepresented in geochemical and petrological studies. Here, we present whole rock major and trace element data as well as $\mathrm{Sr}-\mathrm{Nd}-\mathrm{Hf}$ isotopic compositions for 14 lavas and deposits of 4 Plinian eruptions of the Popocatépetl Volcanic Complex (PVC) in the last $23.5 \mathrm{ka}$, allowing the first comprehensive geochemical characterisation of the dynamics and evolution of its plumbing system. Lavas and pumices of the PVC are andesites-dacites with a narrow compositional range showing no first-order geochemical trends in the last $\sim 23.5$ ka. Trace element and isotope ratios show that PVC magmas are derived from a depleted mantle source with a component of subducted sediments. Assimilation-fractional crystallisation models show that magma compositions are modified to varying degrees by assimilation of lower and upper crust en route to the surface. In the shallow plumbing system, geochemically distinct magmas coexist and undergo extensive mixing and hybridisation, thus buffering erupted whole rock compositions. Only few flank eruptions sample more primitive magmas from deeper reservoirs that circumvented the shallow plumbing system. Some Plinian eruptions caused compositional shifts reflecting reconfigurations of the plumbing system, which also affected subsequent effusive eruptions. Our study thus shows that the geochemical variability of PVC magmas in the last $\sim 23.5 \mathrm{ka}$ is dominated by crustal processes, and magma hybridisation is the primary mechanism to produce the buffered whole rock compositions of the PVC.
\end{abstract}

\section{Resumen}

El estudio de la geoquímica de roca total de elementos mayores y trazas, así como composiciones isotópicas de Sr-Nd-Hf, de 14 coladas de lava y 4 depósitos de erupciones plinianas de los últimos $\sim 23,5$ ka del Complejo Volcánico del Popocatépetl (CVP) nos han permitido hacer por primera vez una caracterización geoquímica integral de la dinámica y evolución de su sistema magmático. Estos datos indican que las lavas del CVP presentan un rango composicional limitado sin variaciones geoquímicas significativas durante los últimos $\sim 23,5 \mathrm{ka}$, que los magmas se originan en un manto empobrecido con un componente de sedimentos subducidos, y que son modificados en distintos grados por asimilación de corteza inferior y superior en su ascenso hacia la superficie. Además, muestran que en el sistema magmático somero coexisten magmas geoquímicamente diferentes que se mezclan e hibridizan eficientemente antes de su erupción, amortiguando así variaciones en las composiciones de roca total que son emitidas. Algunas erupciones de flanco muestrean magmas más primitivos de reservorios más profundos que rodearon el sistema magmático somero. Finalmente, algunas erupciones plinianas causaron modificaciones composicionales que afectaron las erupciones efusivas siguientes y que reflejan reconfiguraciones del sistema magmático.

Keywords: Arc Volcanism; Eruptive History; Crustal Assimilation; Magma Mixing; Effusive-Explosve Transition; Geochemical Evolution

\section{Introduction}

Arc volcanoes are characterised by a variety of eruptive styles, ranging from effusive to violent explosive episodes. Stratovolcanoes in arc settings commonly exhibit several types of activity during an eruptive cycle or even a single eruption (e.g. Novarupta volcano, 
1912: Adams et al. [2006]). Understanding the transition between eruptive styles is a major challenge in modern volcanology, both from a scientific and hazard mitigation perspective. Extensive research has deepened our knowledge of how the interplay of volatile and crystal contents, shallow magma degassing, rheological properties, magma flow rate and conduit geometry impacts the style of eruptive activity [e.g. Wilson et al. 1980; Woods and Koyaguchi 1994; Parfitt and Wilson 1995; Dingwell 1996; Gonnermann and Manga 2003; Ripepe et al. 2005; Edmonds and Herd 2007; Platz et al. 2007; Castro and Gardner 2008; Degruyter et al. 2012]. Such investigations are generally focussed on explosive activity and deposits, often neglecting the voluminous effusive eruptions that dominate the activity of many stratovolcanoes worldwide [Davidson, De Silva, et al. 2000]. However, effusive eruptions are key to understanding the evolution of volcanic complexes and may hold important information about the build-up to and aftermath of explosive eruptions [e.g. Ruprecht and Bachmann 2010; Koleszar et al. 2012; De Maisonneuve et al. 2012; Tepley et al. 2013].

Popocatépetl is an andesitic-dacitic arc stratovolcano with highly variable eruptive activity, situated in a densely populated area in central Mexico (Figure 1). The current eruptive episode started in December 1994, after a 67-year repose period, and has since emplaced and destroyed at least 38 domes [GómezVazquez et al. 2016]. Present-day activity is associated with mild to moderately explosive Vulcanian activity, and ashfall frequently reaches Mexico City and the city of Puebla (Figure 1). However, past activity includes at least six Plinian eruptions in the last $\sim 23.5 \mathrm{ka}$ and the emplacement of at least ten voluminous lava flows. Previous work has focussed on the present-day activity as well as on the Plinian eruptions, whereas only scarce and unsystematic data are available on past interplinian activity. In this study, we present a comprehensive geochemical characterisation of both effusive and explosive eruptions in the last $\sim 23.5 \mathrm{ka}$, which allows us to fully reconstruct the evolution of Popocatépetl's plumbing system, and to identify magmatic processes related to the transition from effusive to explosive activity.

\section{Geological baCKGRound}

\subsection{Eruptive history of Popocatépetl volcano}

Popocatépetl is a Quaternary volcanic complex in Central Mexico, at the front of the Central Trans-Mexican Volcanic Belt (TMVB), an E-W trending volcanic arc generated by the oblique subduction of the Cocos and Rivera plates under the North American plate [Ferrari et al. 2012]. It is the southernmost volcanic centre in a N-S oriented, southward-younging volcanic chain known as the Sierra Nevada, comprising Tláloc, Iztac- cíhuatl and Popocatépetl volcanoes (Figure 1). Modern Popocatépetl is constructed on the remnants of at least two earlier volcanic edifices that were partially destroyed by sector collapses [Mooser 1958; Robin and Boudal 1987; Espinasa-Pereña and Martín-Del Pozzo 2006; Sosa-Ceballos et al. 2015; Siebe et al. 2017]. In this work, Popocatépetl will be used to refer to the modern cone, whereas the term Popocatépetl Volcanic Complex (PVC) refers to the entire volcanic centre including the remnants of previous edifices.

Previous studies relate the earliest preserved volcanism at the PVC to the Nexpayantla edifice ( 330 ka$183 \pm 7$ ka BP; Sosa-Ceballos et al. [2015]), the remnants of which constitute the NW flank of the modern edifice [Espinasa-Pereña and Martín-Del Pozzo 2006; Cadoux et al. 2011; Sosa-Ceballos et al. 2015]. After the sector collapse of the SSW flank of Nexpayantla volcano, construction of Ventorrillo volcano began inside the collapse caldera, with the oldest dated rocks yielding an ${ }^{40} \mathrm{Ar} /{ }^{39} \mathrm{Ar}$-age of $96 \pm 8 \mathrm{ka}$ BP [Sosa-Ceballos et al. 2015]. Ventorrillo lavas and pyroclastic deposits make up large parts of the proximal cone $\mathrm{W}$ of the current vent [Espinasa-Pereña and Martín-Del Pozzo 2006; Sosa-Ceballos et al. 2015], while other Ventorrillo lavas have travelled up to $16 \mathrm{~km}$ from the vent in the northeast (Xalitzintla) and east (Ixtepec and Metepec) (Figure 2). The southern sector of Ventorrillo partly collapsed at $\sim 23.5 \mathrm{ka} \mathrm{BP}$, triggering the Tochimilco Pumice Plinian eruption (TP), which was assigned a VEI of 5 (Volcanic Explosivity Index; Newhall and Self [1982]) and described in detail as the White Pumice Plinian eruption by Siebe et al. [2017].

The collapse of the Ventorrillo edifice marked the onset of modern Popocatépetl, construction of which was characterised by voluminous effusive activity punctuated by at least five Plinian eruptions as well as mild explosive periods such as the present-day activity [Siebe et al. 1996; Panfil et al. 1999; Siebe and Macías 2006; Plunket and Uruñuela 2008; Arana-Salinas et al. 2010; Sosa-Ceballos et al. 2012; Siebe et al. 2017]. Early lava flows were emplaced within the collapse caldera of the Ventorrillo volcano towards the south and southeast [Figure 2; Siebe et al. 2017]. The subsequent Pumice with Andesite Plinian eruption (PwA) at $\sim 14.1 \mathrm{ka} B P$ is considered the largest explosive eruption of modern Popocatépetl [VEI 6; Siebe et al. 1999; EspinasaPereña and Martín-Del Pozzo 2006; Sosa-Ceballos et al. 2012; Siebe et al. 2017]. The PwA produced a combined $5.0 \mathrm{~km}^{3}$ of tephra [Siebe et al. 2017] during an initial stage of Vulcanian to subplinian eruptions that escalated into the cataclysmic main stage [Sosa-Ceballos et al. 2012]. After the PwA Plinian eruption, the primary direction of lava emplacement rotated counterclockwise to the NE, where the youngest large-scale lavas are found (Figure 2).

In addition to summit eruptions producing largely proximal lavas, flank eruptions associated with a SWNE trending fault system account for most of the recent 


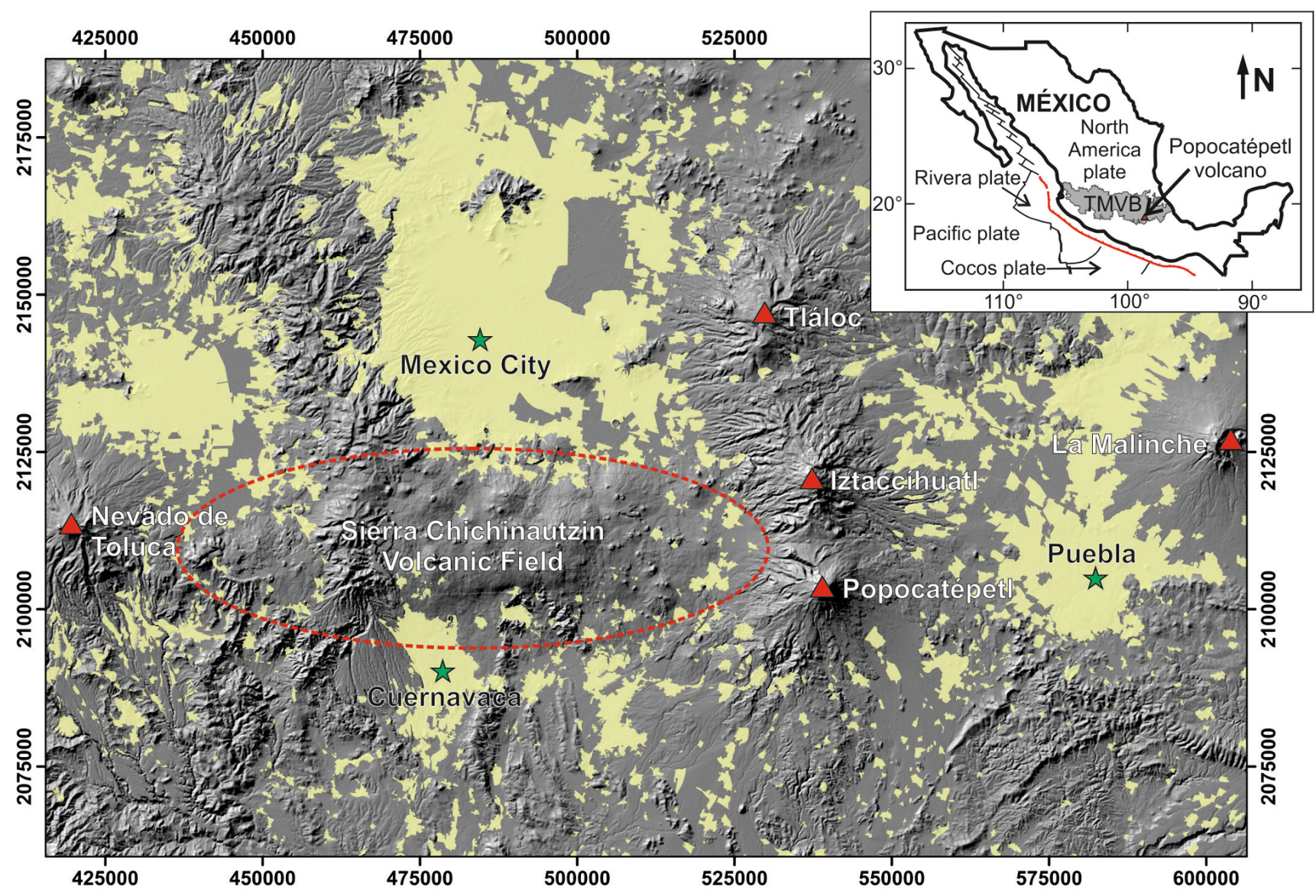

Figure 1: Location of the Popocatépetl Volcanic Complex (PVC) in the eastern part of the Central Trans-Mexican Volcanic Belt (TMVB). Popocatépetl is the youngest volcanic complex in a N-S trending chain including Iztaccíhuatl and Tláloc. Populated areas are shaded in yellow, and green stars denote major population centres.

lavas, especially in the distal sectors. For instance, the youngest prominent lavas, Nealticán and Capula, originated from a fissure on the NE flank, and the Nealticán flow reached more than $17 \mathrm{~km}$ in length (Figure 2). These two flows are bracketed by the two most recent Plinian eruptions, the VEI 6 Yellow Pumice (YP) eruption at 2,150 a BP, and the VEI 4 Pink Pumice (PP) eruption at $\sim 1,100$ a BP [Siebe et al. 1995; Siebe et al. 1996; Panfil et al. 1999; Siebe and Macías 2006; Plunket and Uruñuela 2008]. The YP Plinian eruption consisted of an initial 'blast', followed by the main Plinian pumice fall and subsequent ignimbrite deposition, producing $3.2 \mathrm{~km}^{3}$ of tephra [Siebe et al. 1995; Panfil et al. 1999; Siebe and Macías 2006]. The PP eruption produced $<1.69 \mathrm{~km}^{3}$ tephra during three pulses of pumice fall, accompanied by surges, ashfall and lahars [Siebe et al. 1995; Siebe et al. 1996; Panfil et al. 1999; Siebe and Macías 2006]. Historical accounts show that Popocatépetl's activity since the PP eruption has been dominated by prolonged dome-building and -destruction cycles similar to the eruption ongoing since 1994 [Martín-Del Pozzo et al. 2016]. Vulcanian and Strombolian eruptions related to this activity have produced ash, lapilli and ballistics covering the upper flanks of Popocatépetl [Espinasa-Pereña and Martín-
Del Pozzo 2006], and occasional larger eruptions (VEI 3) in the 1500s as well as in 1664, 1997, and $2001 \mathrm{CE}$ have produced pumice [Martín-Del Pozzo et al. 2016].

\subsection{Previous work}

Previous work on the present-day activity and Plinian eruptions of the last $\sim 23.5 \mathrm{ka}$ has examined source characteristics [e.g. Straub and Martín-Del Pozzo 2001; Schaaf et al. 2005], crustal contamination [e.g. Goff et al. 2001; Siebe 2004; Schaaf et al. 2005], magma mixing and mingling [e.g. Martín-Del Pozzo et al. 2002; Witter et al. 2005; Sosa-Ceballos et al. 2014], degassing processes [e.g. Delgado-Granados et al. 2001; Varley and Armienta 2001; Atlas et al. 2006; Roberge et al. 2009; Cross et al. 2012], physical volcanology [e.g. MartínDel Pozzo et al. 2008; Arana-Salinas et al. 2010; SosaCeballos et al. 2012; Gómez-Vazquez et al. 2016; Siebe et al. 2017], and hazards related to eruptions [e.g. Siebe et al. 1996; Siebe et al. 1999; Macías and Siebe 2005; Bonasia et al. 2013]. Sosa-Ceballos et al. [2015] studied lavas of previous PVC edifices $>96 \pm 8 \mathrm{ka} \mathrm{BP}$, but data for more recent lavas is sparse. Only the Nealticán and Atlimiyaya lavas have been previously characterised 

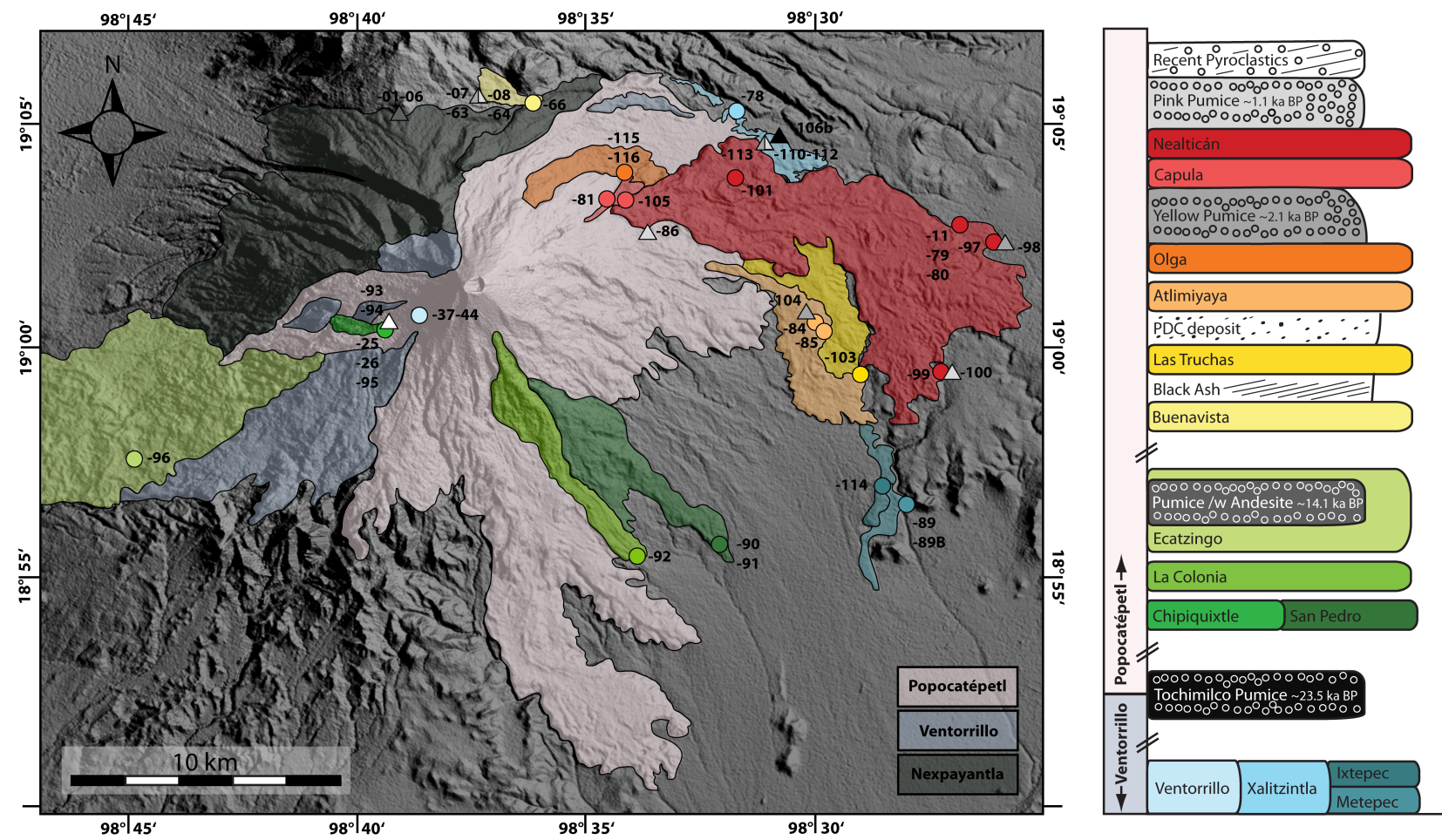

Figure 2: Geological map of the Popocatépetl Volcanic Complex (PVC) and stratigraphy of the current edifice. For clarity, only effusive units are shown. Previous edifices are outlined in muted colours, lavas of the last $\sim 23.5$ $\mathrm{ka}$ are coloured blue to red according to their relative ages. Sample locations are indicated as circles (lavas) and triangles (pumices). Sample numbers are given without the prefix (POP) for the sake of clarity.

for major, trace and radiogenic isotope compositions [Schaaf et al. 2005]. Major and some trace element data are available for the Metepec [Robin 1984; Conte et al. 2004; Espinasa-Pereña and Martín-Del Pozzo 2006] and Buenavista [Nixon 1989] lavas. Boudal and Robin [1988] present some major and trace element data for lavas from the east flank, but they lack GPS coordinates that would allow discrimination of lavas. To the best of our knowledge, no geochemical data have been published on the SW Ventorrillo, Xalitzintla, Ixtepec, La Colonia, Ecatzingo, Las Truchas, Olga and Capula lavas.

\section{Samples ANd Methods}

\subsection{Sampling strategy}

In view of the limited exposure of lavas at the densely vegetated PVC, and the preservation issues associated with minor explosive eruptions, every effort has been made to produce the most detailed and comprehensive record of eruptive activity at the PVC in the past $\sim 23.5 \mathrm{ka}$. Ten lavas of the most recent Popocatépetl edifice and four lavas of the preceding Ventorrillo edifice were identified, mapped and sampled in three field campaigns during 2014-2016 (Figure 2). Stratigraphic relationships between the units were established and a geological map produced based on field observations in conjunction with a detailed survey of aerial photographs, digital elevation models, and published stratigraphic columns [Figure 2; Espinasa-Pereña and Martín-Del Pozzo 2006; Siebe et al. 2017]. Sample locations are shown in Figure 2 and GPS coordinates are given in Supplementary Data 1 (Table S1.1). Whenever possible, each effusive unit was sampled at several locations covering different lobes, however, inaccessible terrain and thick sediment cover prevented extensive sampling in many cases. Excellent exposure of the most recent Nealticán lavas allowed for detailed sampling of discrete proximal and distal lobes, which are interpreted to represent early (POP-101), main (POP$11,-79,-80,-97)$ and late (POP-99) stages of the prolonged fissure eruption (Figure 2).

In addition to the suite of 37 lava samples from 19 locations around the volcano, pumice samples of the four most prominent Plinian eruptions of the last $\sim 23.5 \mathrm{ka}$ were collected (Figure 2). The TP Plinian eruption and the entire eruptive sequence of the PwA Plinian eruption were sampled at single locations, and samples of the PP and YP Plinian eruptions were collected at four different localities, respectively. In addition, two postPP pumice samples (<1100 ys BP) and a ballistic block related to present-day activity were collected (Figure 2). The Ochre Pumice Plinian eruption, dated at $\sim 5 \mathrm{ka} \mathrm{BP}$ and described by Arana-Salinas et al. [2010], was not 
sampled in this study due to uncertain field relationships.

Finally, five crustal xenoliths were sampled, including two $\mathrm{dm}$-sized granodiorites from the PwA deposits, as well as a skarn, a fine-grained Tertiary rhyolite with contact reactions, and a $\sim 1 \mathrm{~m}^{3}$ block composed of monomineralic anhydrite from the Nealticán lava.

\subsection{Analytical methods}

Care was taken in the field to sample fresh lava, avoiding stained surfaces and rocks showing signs of alteration such as incipient pyroxene and plagioclase weathering. Whenever possible, large pumice clasts $(>5 \mathrm{~cm})$ were sampled and weathered crust removed. Samples were cleaned in MQ water (Milli-Q, resistivity $>18.2 \mathrm{M} \Omega . \mathrm{cm}$ at $25^{\circ} \mathrm{C}$ ) and powdered to particle sizes $<2 \mu \mathrm{m}$ using a Fritsch Pulverisette jaw crusher and a Retsch PM100 planetary ball mill with a $250 \mathrm{~mL}$ agate drum at the Natural History Museum, London. A detailed discussion of the analytical methods used in this study can be found in Appendix A, and data on the accuracy and repeatability of respective methods are compiled in Supplementary Data 1.

Powdered bulk rock samples were analysed for major element compositions at Activation Laboratories Ltd., Ancaster, Canada, using X-ray Fluorescence analysis. United States Geological Survey (USGS) reference materials BCR-2, AGV-2 and BHVO-2 were processed as unknowns, showing a relative deviation from recommended values of $<5 \%$ and a repeatability of $<5.5 \%$ 2 SD for major elements (see Supplementary Data 1: Table S1.2). Trace element concentrations were determined on an Agilent 8800 Triple Quadrupole inductively coupled plasma mass spectrometer (ICP-MS) at the Open University, Milton Keynes, and on an Agilent 7700x ICP-MS at the Natural History Museum, London. Replicate measurements of USGS reference material BCR-2 $(n=10)$ indicates a repeatability of $<7 \% 2$ $\mathrm{SD}$ and a relative deviation from recommended values of $<5 \%$ for most elements (see see Supplementary Data 1: Table S1.3).

Sample digestion, chromatographic separation and analysis of $\mathrm{Sr}$ and $\mathrm{Nd}$ isotopic compositions of all samples, as well as Hf isotopic compositions on a representative subset of 21 samples were determined at the MAGIC laboratories at Imperial College London. Strontium isotopic compositions were analysed on a Thermo Finnigan Triton thermal ionization mass spectrometer. The instrumental precision within a single sample run is $\leq 6 \mathrm{ppm} 2 \mathrm{SE}$. Aliquots of USGS reference material BCR-2 digested with the samples and measured during the analysis period yield an average of ${ }^{87} \mathrm{Sr} /{ }^{86} \mathrm{Sr}=0.705008 \pm 7(2 \mathrm{SD} ; n=14$; see see Supplementary Data 1: Table S1.4), in agreement with the recommended value of ${ }^{87} \mathrm{Sr} /{ }^{86} \mathrm{Sr}=0.705013 \pm 10$ [Weis et al. 2006].

Neodymium and Hf isotopic compositions were anal- ysed on a $\mathrm{Nu}$ Instruments $\mathrm{Nu}$ Plasma $\mathrm{HR}$ multicollector ICP-MS. Instrumental precisions within single runs are $\leq 12 \mathrm{ppm} 2 \mathrm{SE}$ for $\mathrm{Nd}$ and $\leq 6 \mathrm{ppm} 2 \mathrm{SE}$ for Hf measurements. Aliquots of BCR-2 measured during the analysis period yield an average value of ${ }^{143} \mathrm{Nd} /{ }^{144} \mathrm{Nd}$ $=0.512637 \pm 11(2 \mathrm{SD} ; n=48)$ and ${ }^{176} \mathrm{Hf} /{ }^{177} \mathrm{Hf}=$ $0.282866 \pm 7$ ( 2 SD; $n=5$; see Supplementary Data 1: Table S1.4), in agreement with the recommended values of ${ }^{143} \mathrm{Nd} /{ }^{144} \mathrm{Nd}=0.512638 \pm 11$ [Weis et al. 2006] and ${ }^{176} \mathrm{Hf} /{ }^{177} \mathrm{Hf}=0.282870 \pm 8$ [Weis et al. 2007]. Reported ${ }^{143} \mathrm{Nd} /{ }^{144} \mathrm{Nd}$ ratios are averages of multiple sample measurements, and the 2 SD uncertainties given are either the standard deviations of these averages, or of the BCR-2 averages analysed with the samples, whichever is larger.

\section{Results}

\subsection{Major and trace elements}

Whole rock major and trace element concentrations of PVC lavas, pumices and xenoliths are compiled in Supplementary Data 1 (Table S1.1). Lavas and pumices from the Popocatépetl and Ventorrillo edifices are andesites and dacites (Figure 3), defining a narrow subalkaline range with dominantly intermediate silica contents $\left(\mathrm{SiO}_{2}=61-65\right.$ wt.\%). Lower silica contents observed for some pumices coincide with low alkali metal concentrations and high LOI values, and are interpreted to reflect secondary alteration processes.

The majority of effusive and explosive samples fall within the published range of Plinian eruptions of the past $\sim 23.5$ ka [dashed field in Figure 3; Siebe et al. 1999; Schaaf et al. 2005; Larocque et al. 2008; AranaSalinas et al. 2010; Sosa-Ceballos et al. 2012; SosaCeballos et al. 2014]. This compositional range is significantly smaller than published data for the present-day activity [white field in Figure 3; Straub and MartínDel Pozzo 2001; Schaaf et al. 2005; Witter et al. 2005; Torres-Alvarado et al. 2011]. The effusive Chipiquixtle flank eruption $\left(\mathrm{SiO}_{2}=57-58 \mathrm{wt} . \%\right)$, one of the oldest units of the Popocatépetl edifice, shows the lowest $\mathrm{SiO}_{2}$ and highest $\mathrm{MgO}$ concentrations of the PVC. Closely related in time to the primitive Chipiquixtle eruption, the La Colonia lava in the SE shows the most evolved bulk rock compositions of the last $\sim 23.5 \mathrm{ka}$. Pumices from explosive eruptions of the last $\sim 23.5 \mathrm{ka}$ show less compositional variability than lavas (Figures 3 and 4), and only the PwA is distinguished by less evolved major element compositions. Trace element concentrations show limited variability over time for both explosive and effusive eruptions. The compositional variability found in eruptions since 1994 exceeds the range exhibited in the past $\sim 23.5 \mathrm{ka}$ for most elements (Figure 4). Popocatépetl and Ventorrillo volcanic rocks show features typical of subduction zone magmatism, including enrichment of LILE by a factor of up to $\sim 100$ com- 


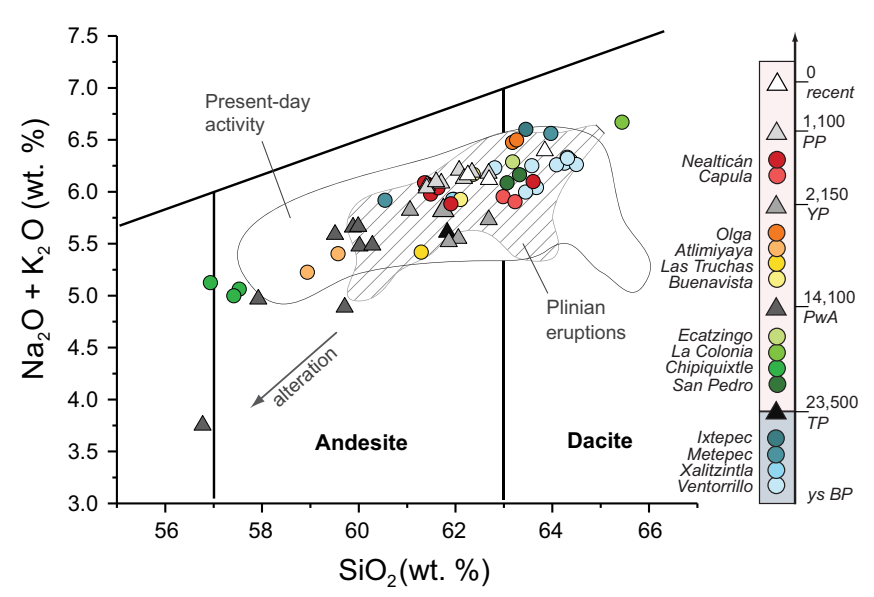

Figure 3: Total alkali vs silica diagram after Le Bas et al. [1986] for effusive and explosive eruptions of the Ventorrillo and Popocatépetl edifices. Effusive eruptions are represented by circles and explosive by triangles. $\mathrm{PP}=$ Pink Pumice Plinian Eruption; YP = Yellow Pumice Plinian Eruption; PwA = Pumice with Andesite Plinian Eruption; TP = Tochimilco Pumice Plinian Eruption. Present-day activity data compiled from Straub and Martín-Del Pozzo [2001], Schaaf et al. [2005], Witter et al. [2005], and Torres-Alvarado et al. [2011]. Plinian eruptions (dashed field) from Siebe et al. [1999]; Schaaf et al. [2005]; Larocque et al. [2008]; Arana-Salinas et al. [2010]; Sosa-Ceballos et al. [2012] and Sosa-Ceballos et al. [2014].

pared to primitive mantle [Sun and McDonough 1989], a steep LREE slope $\left(\mathrm{La}_{N} / \mathrm{Sm}_{N}=2.1-2.8\right)$, pronounced negative anomalies for the high field strength elements $\mathrm{Nb}, \mathrm{Ta}$ and $\mathrm{Ti}$, and a strong positive $\mathrm{Pb}$-anomaly. However, $\mathrm{Zr}$ and Hf do not display negative anomalies, and no significant $\mathrm{Eu}$ anomaly is observed $\left(\mathrm{Eu} / \mathrm{Eu}^{*}=0.83-\right.$ 1.01). The HREE show flat patterns $\left(\mathrm{Tb}_{N} / \mathrm{Yb}_{N}=1.3-\right.$ 1.7), with the steepest slopes for the PwA and PP explosive eruptions. Compositional differences between different units of the Popocatépetl and Ventorrillo edifices are subtle and manifest themselves in absolute enrichment levels rather than in changes in overall trace element patterns. The most enriched samples are the PwA pumices and the units since the YP Plinian eruption $\sim 2150$ a BP, which are on average $15 \%$ more enriched than the lavas erupted between the PwA and the YP Plinian eruptions. Overall, trace element enrichments and patterns of the PVC resemble those of the bulk continental crust (Figure 4).

\section{2 $\mathrm{Sr}-\mathrm{Nd}-\mathrm{Hf}$ isotopes}

Table 1 presents $\mathrm{Sr}-\mathrm{Nd}-\mathrm{Hf}$ isotopic compositions of the Popocatépetl and Ventorrillo edifices. Both lavas and pumices fall within the mantle array for $\mathrm{Sr}$ and $\mathrm{Nd}$ isotope compositions (inset in Figure 5), and most overlap with literature data for Plinian eruptions of the PVC

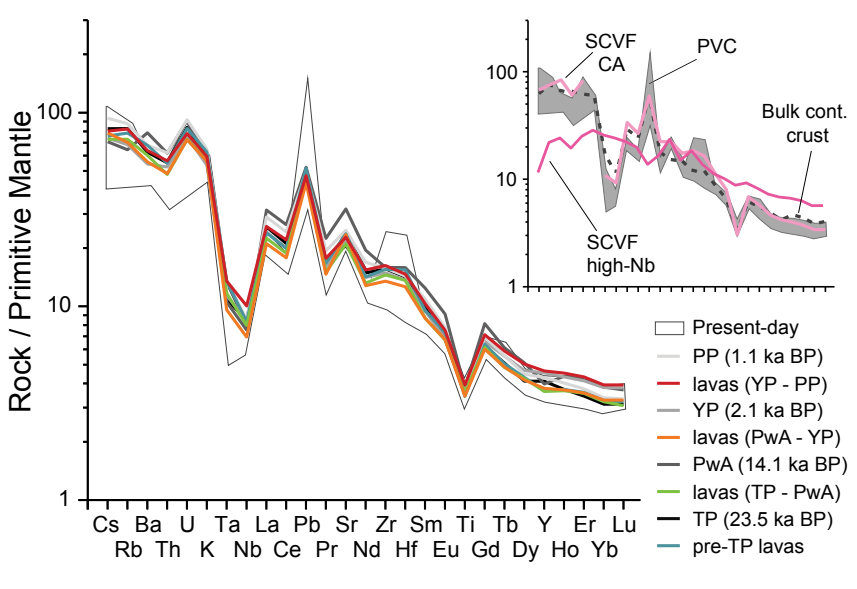

Figure 4: Trace element concentrations normalised to primitive mantle [Sun and McDonough 1989] for major Plinian eruptions and the respective interplinian averages, based on all effusive samples. Present-day activity data from Schaaf et al. [2005]; Torres-Alvarado et al. [2011]. Inset shows PVC range compared to bulk continental crust [Rudnick and Gao 2003] and representative data for high-Nb and calc-alkaline (CA) lavas from the neighbouring Sierra Chichinautzin Volcanic Field (SCVF) [Straub et al. 2015].

[dashed field in Figure 5; Siebe et al. 1999; Schaaf et al. 2005; Arana-Salinas et al. 2010]. Chipiquixtle, the most primitive unit in terms of major and trace elements, shows the most radiogenic ${ }^{143} \mathrm{Nd} /{ }^{144} \mathrm{Nd}$ ratios and least radiogenic ${ }^{87} \mathrm{Sr} /{ }^{86} \mathrm{Sr}$ ratios of this study, while literature data of present-day activity extends to even more radiogenic $\mathrm{Nd}$ isotopic compositions [white field in Figure 5; Schaaf et al. 2005; Torres-Alvarado et al. 2011]. The most radiogenic Sr isotope signatures extend beyond the published range for the PVC and include samples from the Ventorrillo, Capula and Nealticán lavas, and notably from the YP Plinian eruption. Ventorrillo, Nealticán and YP samples from other sample locations trend towards less radiogenic ${ }^{87} \mathrm{Sr} /{ }^{86} \mathrm{Sr}$ ratios, in particular the YP, which show a bimodal distribution encompassing nearly the entire isotopic range. A similar bimodal distribution, albeit less pronounced, is observed for the pumices of the PwA. The narrow linear trend along the mantle array defined by the Chipiquixtle-Yellow Pumice trajectory is expanded to more radiogenic ${ }^{87} \mathrm{Sr} /{ }^{86} \mathrm{Sr}$ ratios at similar ${ }^{143} \mathrm{Nd} /{ }^{144} \mathrm{Nd}$ ratios by TP, PP and present-day samples as well as lavas of all ages. Hafnium isotopic compositions determined for a subset of samples show a positive correlation with $\mathrm{Nd}$ isotopic compositions, falling along the present-day terrestrial array [Figure 6; Vervoort et al. 2011]. Samples define a limited range of $\mathrm{Hf}$ isotopic compositions from $\varepsilon \mathrm{Hf}=8.36$ (Chipiquixtle) to 6.64 (Nealticán), except the Capula lava and one sample of the preceding YP Plinian eruption, which show significantly less radiogenic Hf compositions $(\varepsilon H f=4.61$ and 5.31 , respectively). Similar to $\mathrm{Sr}-$ 


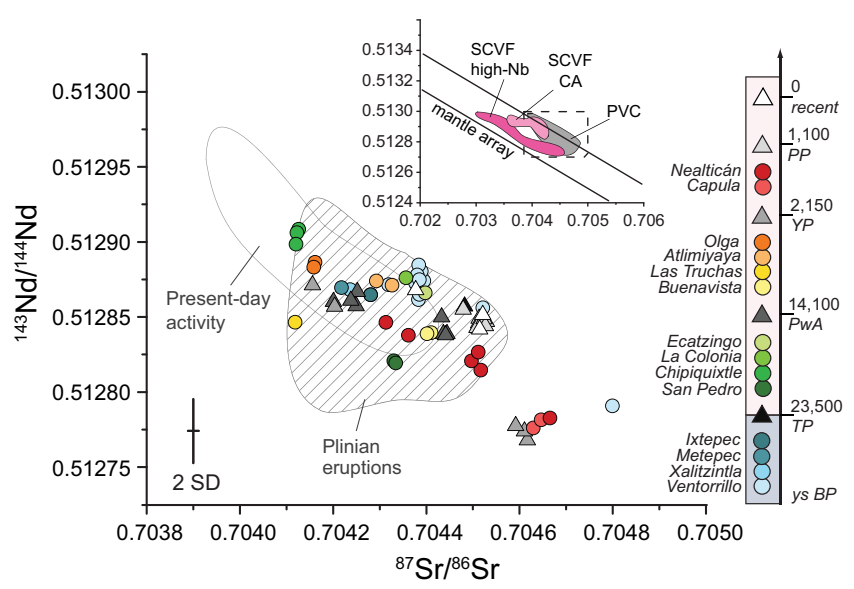

Figure 5: $\mathrm{Sr}-\mathrm{Nd}$ isotope systematics for Ventorrillo and Popocatépetl lavas and pumices. For comparison, literature data for present-day activity [Schaaf et al. 2005; Torres-Alvarado et al. 2011] and Plinian eruptions [Siebe et al. 1999; Schaaf et al. 2005; AranaSalinas et al. 2010] are shown. Inset shows observed range from $\mathrm{PVC}$ compared to high- $\mathrm{Nb}$ and calc-alkaline series of the SCVF [Straub et al. 2015].

Nd isotope compositions, the YP samples display a bimodal distribution.

\section{Discussion}

In the following sections, we use our new chemical constraints to investigate the petrogenesis of the PVC. First, source characteristics of the sub-arc mantle are constrained. We then examine magmatic evolution during the last $\sim 23.5 \mathrm{ka}$ to identify potential geochemical trends over time, changes related to transitions from effusive to explosive activity and vice versa, and differences between summit and flank eruptions. New data for xenoliths sampled from PVC lavas and pumices are used to revisit the potential for lower and upper crustal contamination to modify PVC magmas. Finally, we discuss our findings in the context of magma mixing and hybridisation to constrain the architecture and dynamics of the plumbing system of the PVC.

\subsection{Mantle source characteristics}

The TMVB produces volcanic rocks with starkly contrasting geochemical signatures in close spatial association, which is widely attributed to a heterogeneous mantle source [e.g. Luhr 1997; Wallace and Carmichael 1999; Ferrari et al. 2001; Petrone et al. 2003]. In the Sierra Chichinautzin Volcanic Field (SCVF) west of the PVC (Figure 1), calc-alkaline monogenetic centres coexist with OIB-type, high-Nb lavas on a km-scale [Figures 4, 5 and 6; Verma 1999; Siebe 2004; Schaaf et al. 2005; Straub et al. 2013]. This spatial association has been argued to reflect small-scale mantle

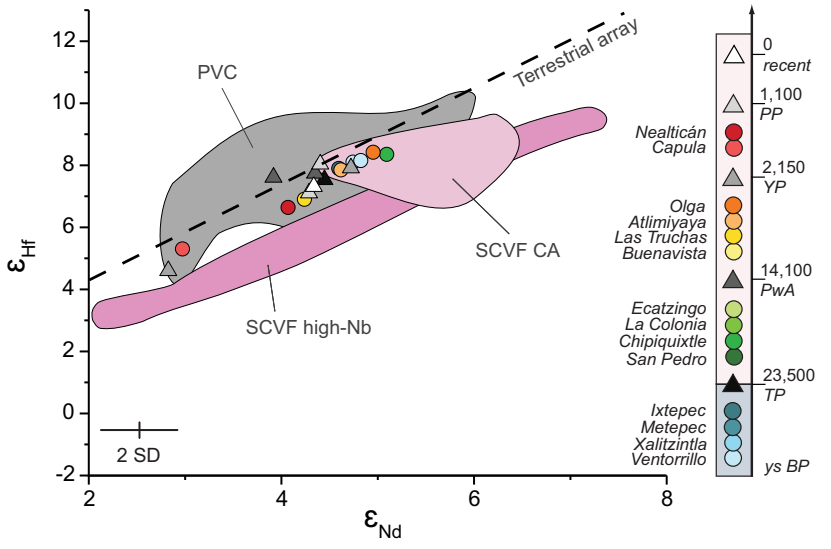

Figure 6: $\varepsilon$ Hf vs. $\varepsilon \mathrm{Nd}$ of selected Ventorrillo and Popocatépetl lavas and pumices. Present-day terrestrial array from Vervoort et al. [2011], SCVF data from Straub et al. [2015], PVC data from Straub et al. [2015] and Cai et al. [2014].

heterogeneities, with depleted and undepleted mantle domains of $<\mathrm{km}$ size in the mantle wedge [e.g. Siebe 2004]. To explain this heterogeneity, Wallace and Carmichael [1999] proposed corner flow as a mechanism to transport unmodified back-arc mantle into the depleted melting region beneath central Mexico, while Ferrari [2004] invoked propagation of a slab detachment to cause upwelling of deep-seated mantle material.

While OIB-type lavas are thought to derive from primitive mantle domains [Gomez-Tuena et al. 2006; Cai et al. 2014; Straub et al. 2015], several contrasting petrogenetic models have been proposed to explain geochemical features of calc-alkaline lavas of the central TMVB.

- Partial melting of sub-arc mantle and veins of pyroxenites formed by mantle reaction with hydrous slab components [e.g. Luhr 1997; Straub et al. 2008; Straub et al. 2011; Straub et al. 2013];

- Melts of the subducting slab and overlying sedimentary strata contribute to partial melts of variably depleted mantle [Gomez-Tuena et al. 2006; Cai et al. 2014];

- Subduction-eroded fore-arc granodioritic basement and altered oceanic crust are added to the depleted mantle in the form of 'slab diapirs' before melting [Straub et al. 2015].

Our new geochemical dataset allows an evaluation of magma petrogenesis at the PVC with respect to existing models of the sub-arc mantle beneath the Central TMVB.

Compared to the bimodal compositional trends of the SCVF (calk-alkaline vs. OIB-type), PVC rocks show little variability in terms of major and trace element compositions as well as $\mathrm{Sr}-\mathrm{Nd}-\mathrm{Hf}$ isotopes (Figures 4, 
Table 1 - Sr-Nd-Hf isotopic composition of Popocatépetl and Ventorrillo rocks, presented in chronological order.

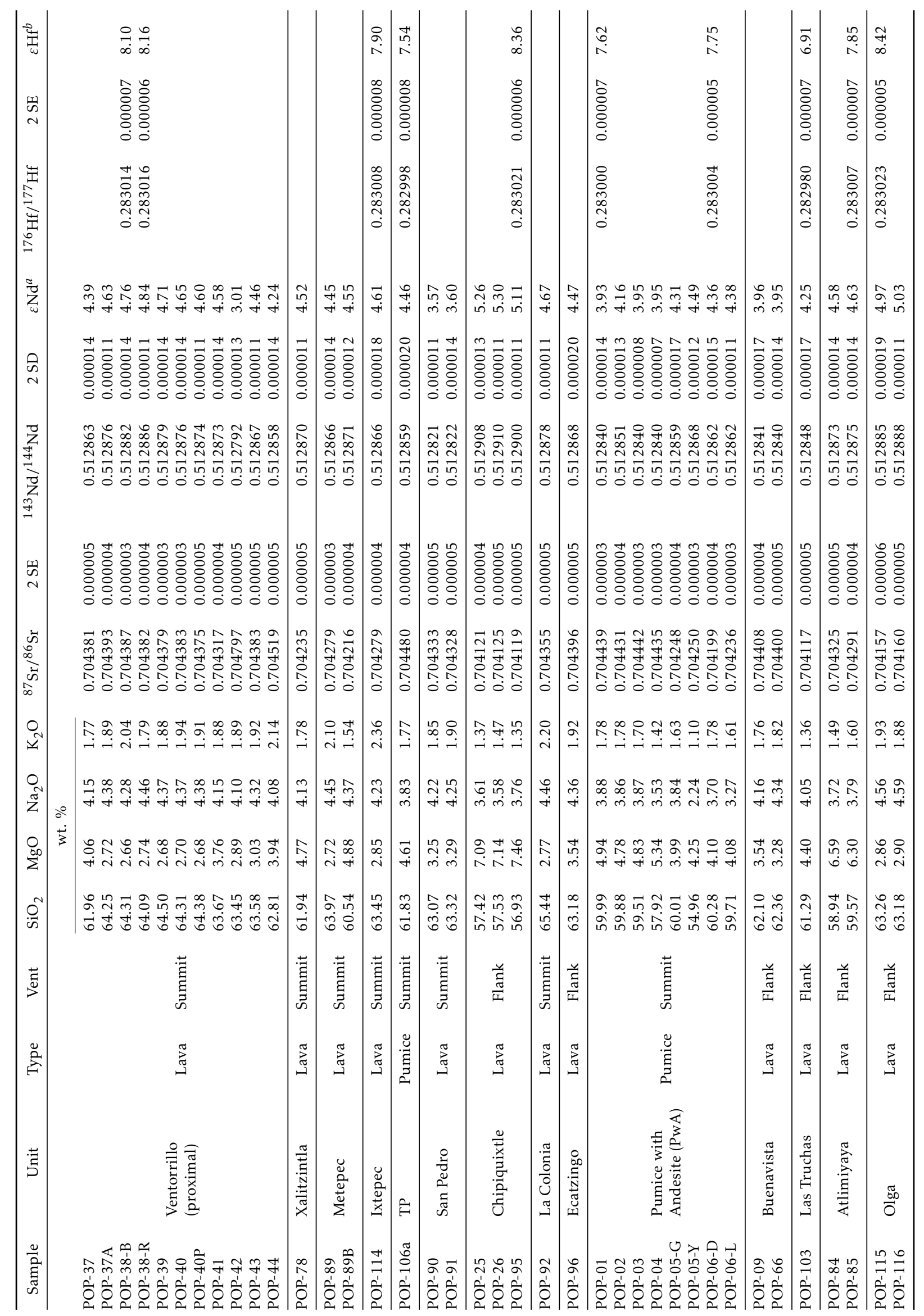

${ }^{a}$ normalised to CHUR $\left({ }^{143} \mathrm{Nd} /{ }^{144} \mathrm{Nd}=0.512630\right.$; Bouvier et al. [2008] $)$

${ }^{b}$ normalised to CHUR $\left({ }^{176} \mathrm{Hf} /{ }^{177} \mathrm{Hf}=0.282785\right.$; Bouvier et al. [2008]) 
Table 1: [cont.] - Sr-Nd-Hf isotopic composition of Popocatépetl and Ventorrillo rocks.

\begin{tabular}{|c|c|c|c|c|c|c|c|}
\hline & & & & & & & \\
\hline 7 & $\begin{array}{ll}\tilde{\sigma} & \vec{\sigma} \\
+\end{array}$ & $\overrightarrow{m_{i}}$ & 节 & $\vec{\square}$ & $\tilde{N}$ & $\begin{array}{lll}0 & 0 \\
0 & 1 \\
\infty & 0 \\
\infty & \infty\end{array}$ & \\
\hline & $\begin{array}{ll}\hat{0} & \hat{0} \\
0 & 0 \\
0 & 0 \\
0 & 0 \\
0 & 0\end{array}$ & $\begin{array}{l}0 \\
\vdots \\
0 \\
\vdots \\
0\end{array}$ & $\begin{array}{l}0 \\
\vdots \\
0 \\
\vdots \\
0\end{array}$ & $\begin{array}{l}\hat{0} \\
0 \\
0 \\
0 \\
0\end{array}$ & $\begin{array}{l}0 \\
\stackrel{0}{0} \\
\vdots \\
0 \\
0\end{array}$ & $\begin{array}{ll}\infty & 1 \\
0 & 0 \\
0 & 0 \\
\vdots & 0 \\
0 & 0 \\
0 & 0 \\
0 & 0\end{array}$ & ఏ \\
\hline & 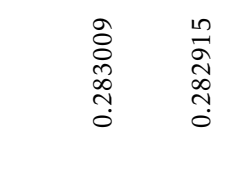 & $\begin{array}{l}0 \\
\widetilde{N} \\
\infty \\
\sim \\
0 \\
0\end{array}$ & 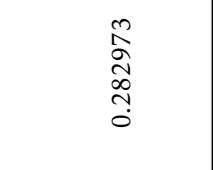 & 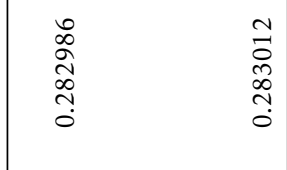 & 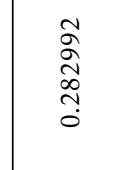 & $\begin{array}{lll} & 0 & 0 \\
0 & 0 \\
0 & 0 \\
0 & 0 \\
& 0 \\
0 & 0 \\
0\end{array}$ & \\
\hline & 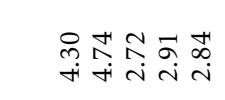 & $\begin{array}{ll}\hat{N} & \sigma \\
i & i\end{array}$ & 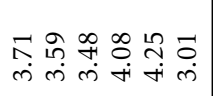 & 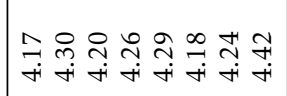 & 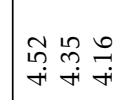 & 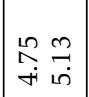 & 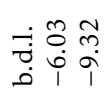 \\
\hline & 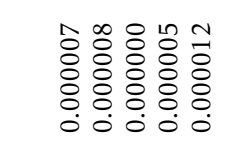 & $\mid \begin{array}{ll}\overrightarrow{5} & 0 \\
0 & 0 \\
0 & 0 \\
0 & 0 \\
0 & 0 \\
0\end{array}$ & 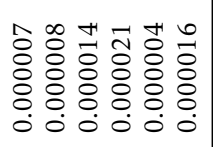 & 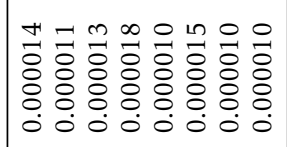 & $\mid \begin{array}{lll}F & \infty & 0 \\
0 & 0 & 0 \\
0 & 0 & 0 \\
0 & 0 & 0 \\
0 & 0 & 0 \\
0 & 0 & 0\end{array}$ & $\mid \begin{array}{ll}0 & 0 \\
0 & 0 \\
0 & 0 \\
0 & 0 \\
0 & 0 \\
0 & 0\end{array}$ & $\begin{aligned} & \overline{0} \\
&-\dot{0} \\
& \dot{0} \\
& \dot{0}\end{aligned}$ \\
\hline & 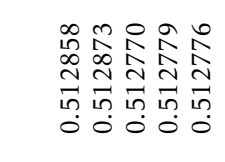 & 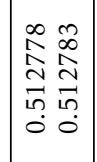 & 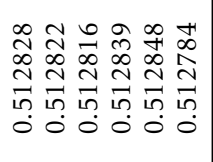 & 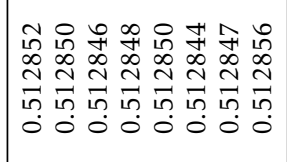 & 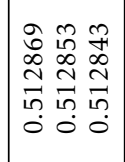 & 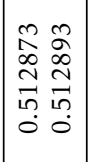 & 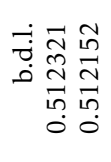 \\
\hline & 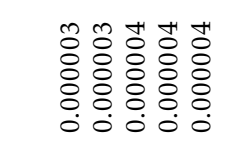 & $\mid \begin{array}{ll}1 & 0 \\
0 & 0 \\
0 & 0 \\
0 & 0 \\
0 & 0 \\
0 & 0 \\
0 & 0\end{array}$ & 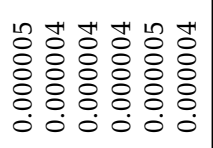 & 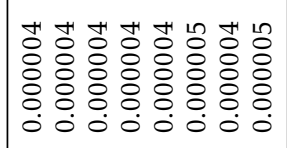 & 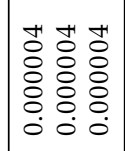 & $\mid \begin{array}{ll} & 0 \\
0 & 0 \\
0 & 0 \\
0 & \vdots \\
0 & 0 \\
0\end{array}$ & 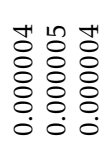 \\
\hline & 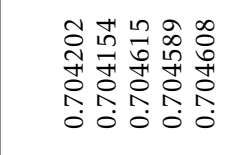 & 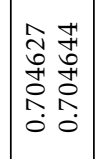 & 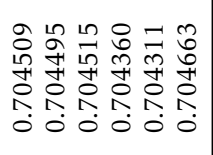 & 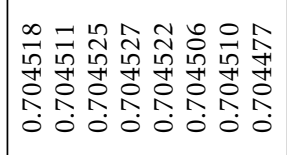 & 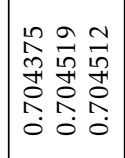 & \begin{tabular}{ll|}
1 & 0 \\
$b$ & 0 \\
0 & 0 \\
\multirow{1}{*}{} & \multirow{1}{0}{} \\
0 & 1 \\
0 & 0 \\
0 & 0
\end{tabular} & 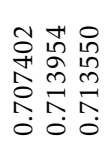 \\
\hline & | & 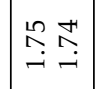 & $\begin{array}{ll}0 \\
\infty\end{array}$ & 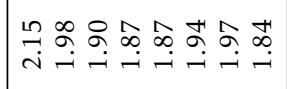 & 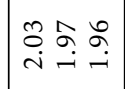 & 官 & 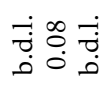 \\
\hline & 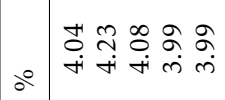 & 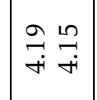 & 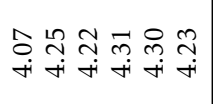 & 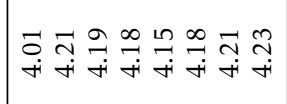 & 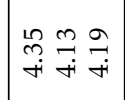 & $\underset{F}{\stackrel{F}{F}} \stackrel{\partial}{\dot{F}}$ & تृ \\
\hline & 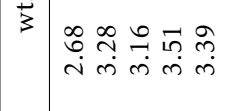 & $\mid \begin{array}{ll}\infty & + \\
0 & 0 \\
\dot{m} & \dot{n}\end{array}$ & 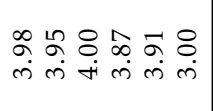 & 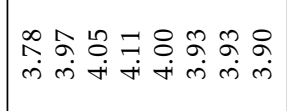 & $\begin{array}{lll}= & n & \\
\dot{m} & \infty & \vec{m} \\
\dot{m} & \dot{m}\end{array}$ & 究 & 它 \\
\hline & 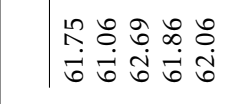 & $\left|\begin{array}{ll}\infty & 0 \\
0 & 1 \\
i & 0 \\
0 & 0\end{array}\right|$ & 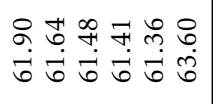 & 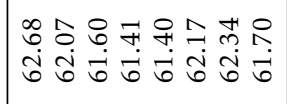 & 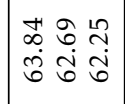 & 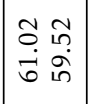 & $\begin{array}{ll}\hat{\alpha} & \infty \\
\dot{m} & \stackrel{\infty}{+}\end{array}$ \\
\hline & 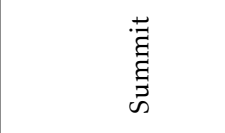 & 营 & $\frac{\breve{m}}{\frac{\text { E }}{I}}$ & $\begin{array}{l}\overrightarrow{\vec{E}} \\
\text { हु } \\
\dot{m}\end{array}$ & 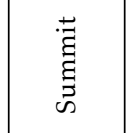 & $\begin{array}{l}\text { है } \\
\text { है } \\
\text { के }\end{array}$ & \\
\hline & 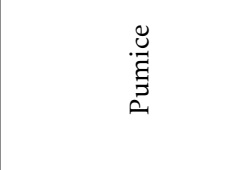 & 㞼 & 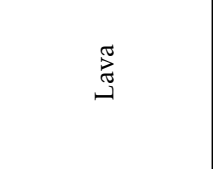 & : & 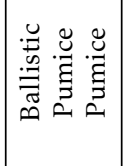 & 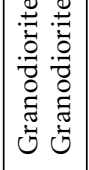 & 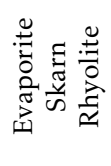 \\
\hline & 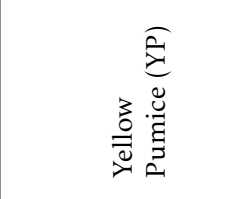 & $\begin{array}{l}\frac{\pi}{3} \\
\frac{\overrightarrow{0}}{0}\end{array}$ & 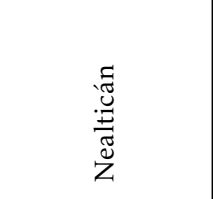 & 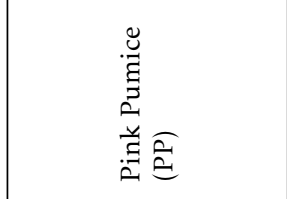 & 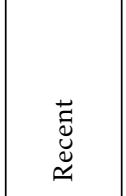 & 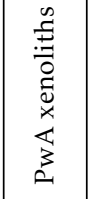 & 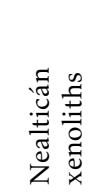 \\
\hline & 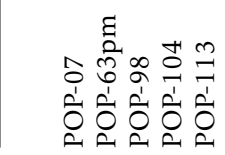 & 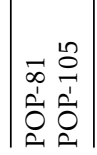 & 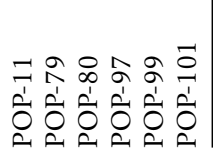 & 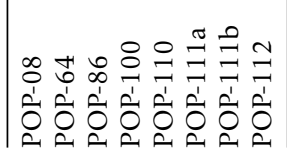 & 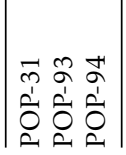 & 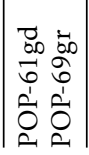 & 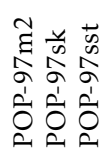 \\
\hline
\end{tabular}

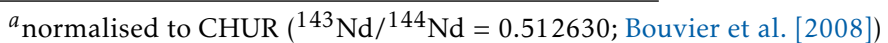

${ }^{b}$ normalised to CHUR $\left({ }^{176} \mathrm{Hf} /{ }^{177} \mathrm{Hf}=0.282785\right.$; Bouvier et al. [2008])
} 
5 and 6). Trace element and $\mathrm{Sr}-\mathrm{Nd}-\mathrm{Hf}$ isotopic ratios of the PVC overlap with the calc-alkaline series of the SCVF (Figures 4 and 5). The PVC rock suite shows no affinity to OIB-type, high-Nb characteristics, which are defined by less enriched LILE and more enriched HREE compared to the PVC (Figure 4) and systematically lower radiogenic ${ }^{87} \mathrm{Sr} /{ }^{86} \mathrm{Sr}$ ratios (inset in Figure 5). Hence, PVC rocks are akin to the calcalkaline series of the SCVF, with no indication for significant mantle source heterogeneity or primitive mantle influence. Indeed, subchondritic $\mathrm{Nb} / \mathrm{Ta}$ ratios (average $\mathrm{Nb} / \mathrm{Ta}=13)$ at $\mathrm{Nb}=4-9 \mathrm{ppm}$ indicate a depleted mantle source (Figure 7A), which has also been proposed for calc-alkaline rocks of the SCVF [Straub et al. 2015]. The chemical characteristics of our sample suite are thus consistent with previous studies of the PVC suggesting a sub-arc background mantle depleted by multiple melting events based on relatively low HFSE abundances and depleted Sr-Nd isotopic signatures [Straub and Martín-Del Pozzo 2001; Schaaf et al. 2005; Straub et al. 2015]. In terms of additions to the depleted mantle beneath the PVC, Straub and Martín-Del Pozzo [2001] invoked melts of subducted slab components, and Gomez-Tuena et al. [2006] extended this hypothesis to propose that direct slab melts dominate the trace element and $\mathrm{Sr}-\mathrm{Nd}-\mathrm{Pb}$ characteristics of Central TMVB rocks, including the PVC. However, a significant contribution of slab melts to PVC magmas is unlikely considering the low $\mathrm{Sr} / \mathrm{Y}$ ratios $<40$ observed ( $\mathrm{Y}=\sim 20 \mathrm{ppm})$. Moreover, fa correlation between $\mathrm{Sr} / \mathrm{Y}$ and ${ }^{87} \mathrm{Sr} /{ }^{86} \mathrm{Sr}$ ratios towards the Sr isotopic ratio of Pacific MORB would be expected if subducted oceanic crust played a key role in the petrogenesis of PVC magmas [Gomez-Tuena et al. 2006], however no such correlation is apparent. Furthermore, the slab melt model of Gomez-Tuena et al. [2006] predicts a correlation between $\mathrm{SiO}_{2}$ concentrations and $\mathrm{Nb} / \mathrm{Ta}$ ratios, which is not observed at the PVC. Similarly, low Ba/Th ratios argue against significant contributions of altered oceanic crust to PVC rocks [Elliott 2003], in contrast to other Quaternary TMVB magmas, which show elevated $\mathrm{Ba} / \mathrm{Th}$ ratios (Figure $7 \mathrm{~B}$ ).

Significant contributions of slab melt or altered oceanic crust to the depleted mantle beneath the PVC are thus considered unlikely. Instead, enriched LREE $\left(\mathrm{La} / \mathrm{Sm}_{N}=2-3\right.$, Figure $\left.7 \mathrm{~B}\right)$ and a strong positive $\mathrm{Pb}$ anomaly (Figure 4) suggest sediment input to the depleted mantle wedge beneath the Central TMVB. This is consistent with the findings of Schaaf et al. [2005], who interpret high $\mathrm{Pb}$ concentration anomalies in PVC rocks to indicate 'fluxing' of background mantle with subducted sediment, similar to the pyroxenite vein model proposed for the TMVB by Straub et al. [2008], Straub et al. [2011], Straub et al. [2013], and Straub et al. [2013]. The potential addition of subduction-eroded granodiorite to the sub-arc mantle beneath the PVC as slab diapirs [Straub et al. 2015] is more difficult to evaluate, because of significant compositional overlap be-

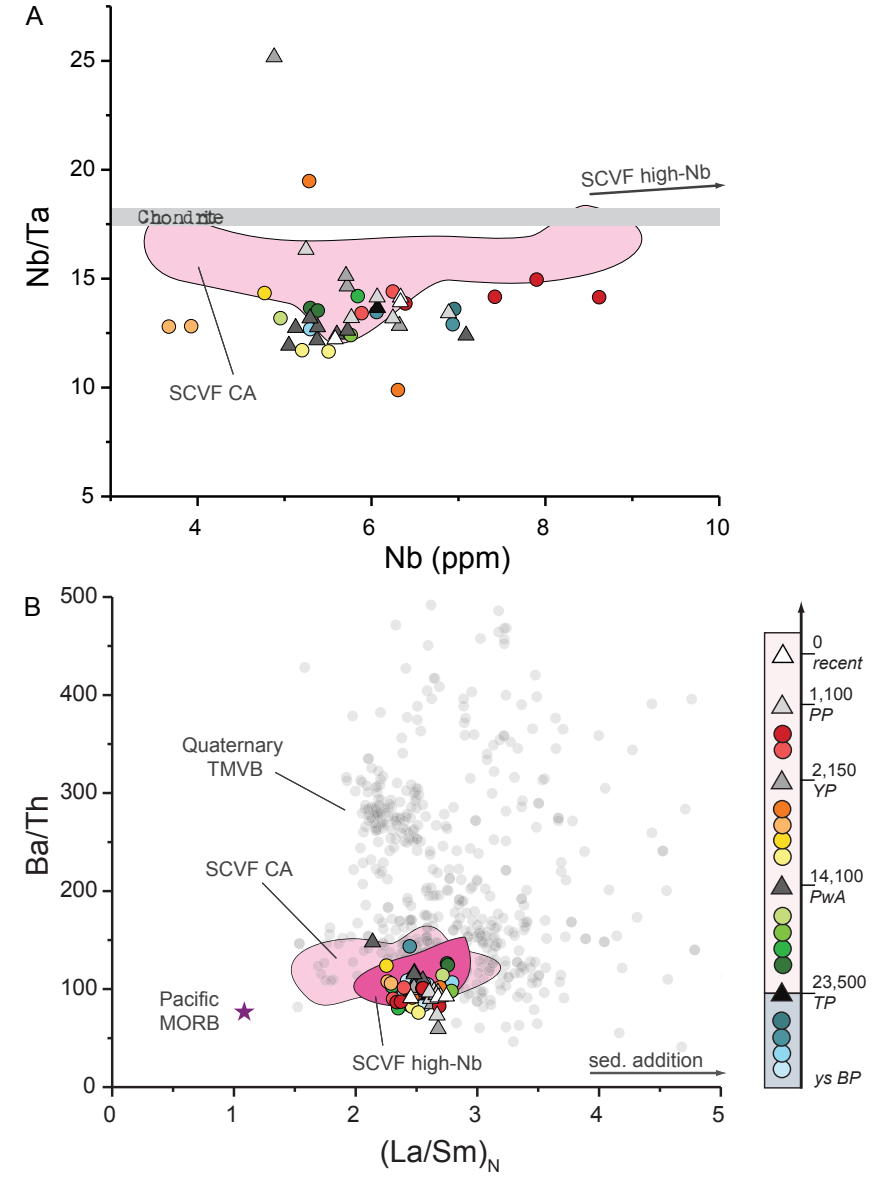

Figure 7: Trace element plots detailing source characteristics of PVC volcanic rocks. [A] $\mathrm{Nb} / \mathrm{Ta} \mathrm{vs} \mathrm{Nb}$, with calc-alkaline SCVF rocks for reference. [B] Ba/Th vs $(\mathrm{La} / \mathrm{Sm}) \mathrm{N}$, with Pacific MORB, SCVF and quaternary volcanic rocks from the TMVB for reference. AOC = Altered Oceanic Crust. SCVF data from Straub et al. [2015]; quaternary TMVB data compiled from GeoRoc; average Pacific MORB data offshore Mexico from PetDB.

tween the PVC and Mexican fore-arc continental granodiorites [Hernández-Pineda et al. 2011; Straub et al. 2015].

The overall compositional range of PVC rocks is narrow compared to the geochemical variability of the neighbouring SCVF, and there is no evidence for a heterogeneous mantle source such as proposed for the latter. To further constrain the stability of the mantle source, the geochemical evolution of the PVC will be reconstructed using our comprehensive dataset of effusive and explosive eruptions in the last $\sim 23.5 \mathrm{ka}$.

\subsection{Temporal geochemical evolution of PVC magmas}

Long-lived arc volcanoes commonly show significant changes in magma compositions over time. This can express itself either as a secular evolution related to a gradual change in the magmatic source (e.g. Cayambe: 
Samaniego et al. [2002]; Vulcano: De Astis et al. [2000]; Santorini: Fabbro et al. [2013]) or in dominant crustal processes (e.g. Ruapehu: Price et al. [2012]; Planchon: Tormey et al. [1995]), or as abrupt changes associated with temporal or permanent reconfigurations of the plumbing system due to large explosive eruptions and/or sector collapse events (e.g. Stromboli: Francalanci et al. [1989]; Colima: Crummy et al. [2014]).

The PVC shows no systematic first-order secular geochemical evolution since $>23.5 \mathrm{ka}$ BP with respect to major and trace element and $\mathrm{Sr}-\mathrm{Nd}-\mathrm{Hf}$ isotope compositions (Figure 8). Effusive and explosive eruptions define long-term narrow compositional ranges, highlighted as the 'main PVC range' in Figure 8, which includes both the oldest lavas and the present-day activity. This substantiates the hypothesis of a homogeneous and stable mantle source, and it further suggests that the plumbing system has buffered the compositions of effusive and explosive eruptions to some degree. However, significant compositional variability is evident both within the main PVC range and beyond (Figure 8). Some of these excursions manifest as isolated flank eruptions sampling more primitive compositions (i.e. Chipiquixtle and Atlimyaya flank eruptions; Figure 8), which might suggest that these eruptions largely bypassed the shallow plumbing system and thus preserve distinct magmatic signatures. On the other hand, Plinian eruptions can cause longerlasting compositional shifts (i.e. PwA and YP; Figure 8), which dominate the geochemistry of subsequent effusive eruptions, thus shaping the geochemical evolution of the PVC. Subtle changes in isotope compositions of effusive eruptions before and after the $14.1 \mathrm{ka}$ BP PwA Plinian eruption (yellow in Figure 8) indicate that the PwA caused a reconfiguration of the plumbing system, resulting in a compositional shift of erupted magmas. Indeed, the initial stage of the PwA Plinian eruption (samples POP-01-04, Table 1; Figure 9) is characterised by more radiogenic ${ }^{87} \mathrm{Sr} /{ }^{86} \mathrm{Sr}$ ratios of $\sim 0.70444$ and the highest $\mathrm{MgO}$ recorded for explosive eruptions at the PVC, while the cataclysmic main stage (samples POP$05-06)$ is associated with less radiogenic ${ }^{87} \mathrm{Sr} /{ }^{86} \mathrm{Sr} \mathrm{ra}-$ tios of $\sim 0.70424$ and more evolved compositions (Figure 9). Neodymium isotopic ratios show a similar albeit less pronounced shift at the transition from initial to main stage of the PwA eruption (Figure 9). This is consistent with isotopic data for minerals and glass reported by Sosa-Ceballos et al. [2014], who suggest that during the early stages of the PwA Plinian eruption a deeper, less evolved magma reservoir with more radiogenic Sr compositions was tapped, and later stages erupted shallower magmas with less radiogenic Sr isotopic signatures. Our geochemical data for the PwA eruption supports this hypothesis, and $\mathrm{Sr}$ isotope data for pre- and post-PwA effusive eruptions further suggest that this shift in the feeding reservoir was longlasting: Sr isotopic signatures of pre-PwA lavas (e.g. La Colonia and Ecatzingo) are similar to those of the initial

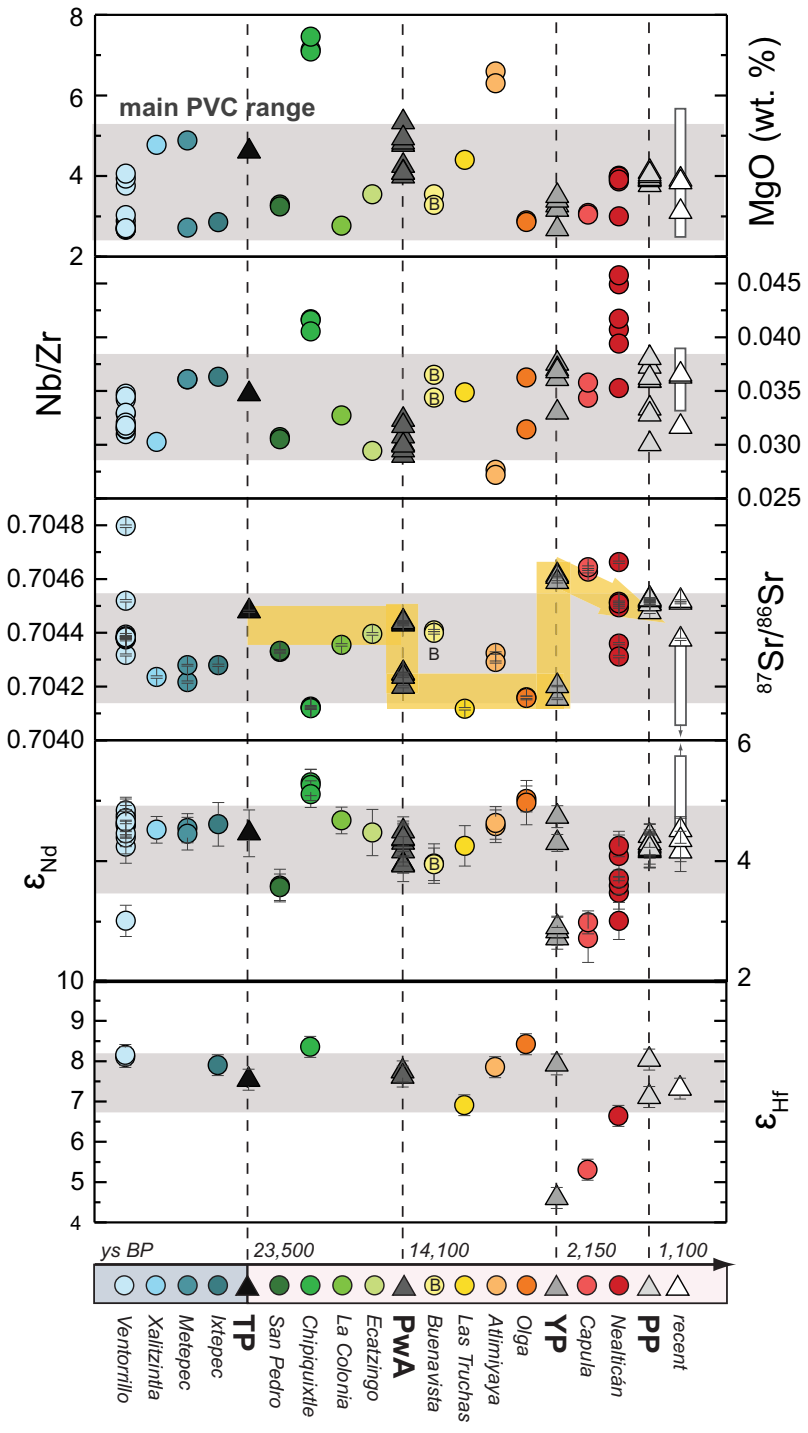

Figure 8: Temporal evolution of geochemical characteristics of the Ventorrillo and Popocatépetl volcanic edifices. Grey bands denote long-term compositional ranges for the majority of eruptions at the PVC, referred to hereafter as the 'main PVC range'. Yellow trend highlights systematic changes in $\mathrm{Sr}$ isotope compositions in lavas and pumices, related to reconfigurations of the plumbing system caused by the PwA and YP Plinian eruptions. White boxes denote data for present-day activity from Straub and Martín-Del Pozzo [2001]; Schaaf et al. [2005]; Witter et al. [2005]; and Torres-Alvarado et al. [2011]. See text for further explanation.

stages of the Plinian eruption, whereas post-PwA lavas scatter around the less radiogenic ${ }^{87} \mathrm{Sr} /{ }^{86} \mathrm{Sr}$ ratios of the main PwA stage (e.g. Las Truchas and Olga; Figure 8). The only outliers to this pattern are the Chipiquixtle and Atlimiyaya flank eruptions, which are inferred to have circumvented the PVC's shallow plumbing system, and the Buenavista flank eruption (marked with a 'B' in Figure 8), which has been argued to be connected to the magmatic system of the neighbouring Iztaccíhu- 


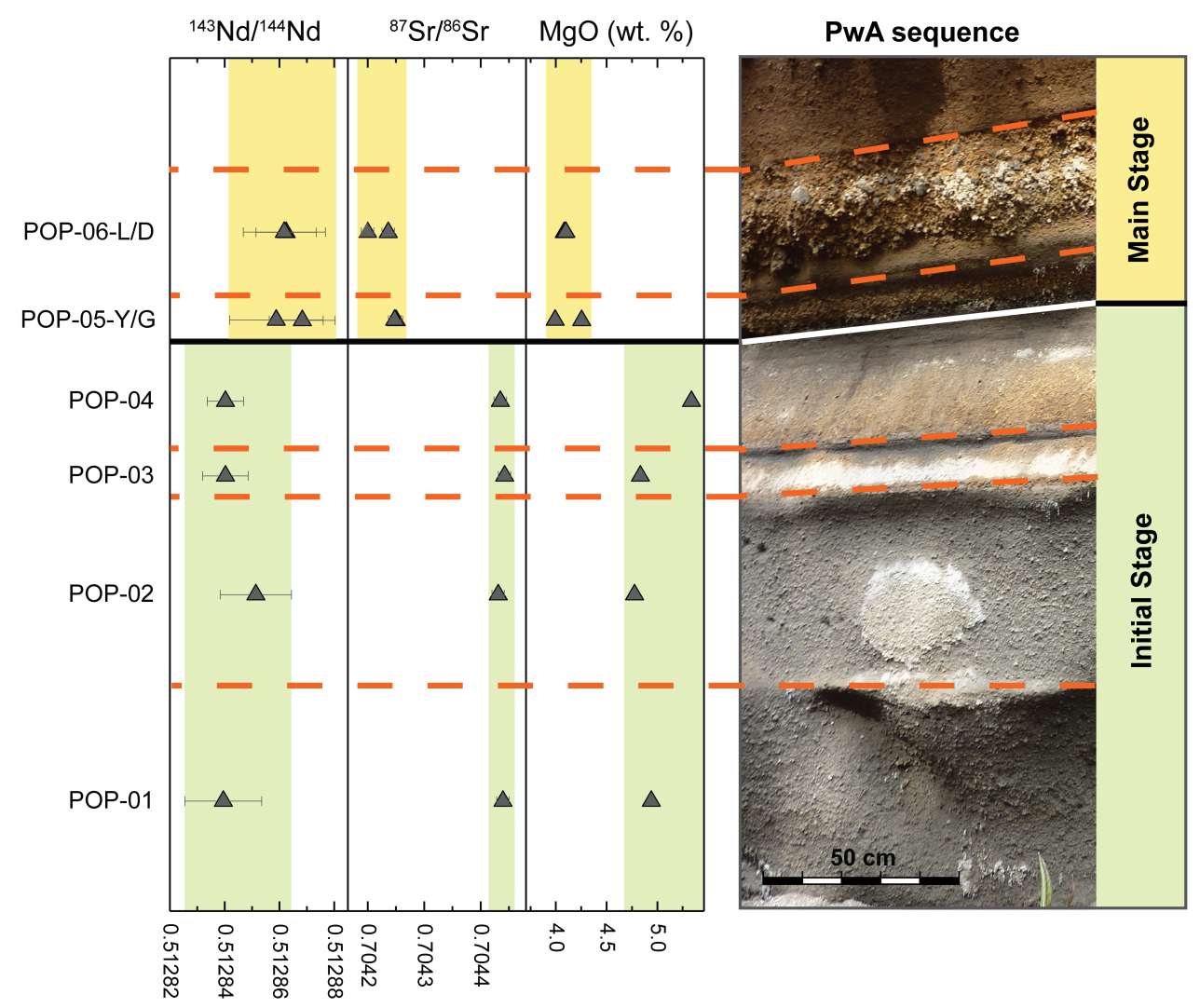

Figure 9: Chemostratigraphy of the PwA Plinian eruption $14.1 \mathrm{ka}$ BP. Sr-Nd isotopic compositions and MgO show a distinct change at the transition from the initial to the main stage of the eruption. See text for further explanations.

atl volcano rather than directly to the PVC [Nixon 1989]. We therefore suggest that the magma reservoir feeding pre-PwA effusive eruptions was largely emptied in the initial stage of the PwA eruption, and that post-PwA lavas were instead predominantly fed by the magma reservoir tapped during the main stage of the PwA Plinian eruption.

The absence of systematic geochemical trends in lavas erupted between the PwA and the YP Plinian eruptions is considered to reflect the relative stability of the plumbing system between $14.1 \mathrm{ka}$ and 2150 a BP. A tendency towards lower $\mathrm{MgO}$ concentrations during this time period (Figure 8) may indicate some degree of melt fractionation, and further secondary variation may be due to recharge with more primitive magma batches and small-scale heterogeneities within the feeding magma reservoir. However, during the YP eruption, $\mathrm{Sr}$ isotopic compositions pinpoint a major shift in the main magma input, from unradiogenic pre-YP ${ }^{87} \mathrm{Sr} /{ }^{86} \mathrm{Sr}$ ratios to some of the most radiogenic values observed at the PVC $\left(\Delta^{87} \mathrm{Sr} /{ }^{86} \mathrm{Sr}=\right.$ 388 ppm; Figure 8). A reciprocal pattern is observed for ${ }^{143} \mathrm{Nd} /{ }^{144} \mathrm{Nd}$ ratios, where the system is reset to the least radiogenic values of the PVC $(\Delta \varepsilon \mathrm{Nd}=-1.4)$. Notably, the distinct shift in isotopic signatures is not reproduced in major and trace element compositions
(Figure 8). Like the PwA, the YP Plinian eruption caused a compositional shift that reverberated in the subsequent effusive activity: the Capula flank eruption as well as a proximal lobe of the following Nealticán eruption (interpreted to represent its early stages; POP101; Figure 2) show major, trace and isotopic compositions similar to the YP eruption (Figure 8). By contrast, distal lava lobes of the Nealticán eruption (inferred to represent later stages; Figure 2) trace the gradual evolution from extreme YP/Capula isotopic signatures back to 'main PVC range' characteristics (Figure 8). This may indicate that during the YP eruption, an evolved magma reservoir with distinct geochemical characteristics was tapped, which also fed the subsequent Capula eruption, before being exhausted and hybridised with the main feeding reservoir during the Nealticán effusive eruption. As a result of this hybridisation process, 'main PVC range' compositions were restored by the time of the PP Plinian eruption. Pumices of the PP eruption show compositions similar to pre-YP lavas, with the exception of $\mathrm{Sr}$ isotope ratios, which are more radiogenic in the PP pumices (Figure 8). Presentday activity is characterised by significant geochemical variability [Figures 3, 4 and 8; Straub and MartínDel Pozzo 2001; Schaaf et al. 2005; Witter et al. 2005; Torres-Alvarado et al. 2011], which is inferred to reflect 
the small-scale, ephemeral compositional heterogeneity of the PVC plumbing system resolved by small eruptions only.

Lavas and pumices of the PVC in the past $\sim 23.5$ ka show no first-order geochemical evolution, pointing to a relatively homogeneous mantle source and a feeder system buffering erupted compositions to a certain extent. However, secondary compositional variations over time suggest a complex plumbing system with several, compositionally distinct magma reservoirs (Figures 8 and 9). To explain this compositional variability, crustal processes need to be invoked. Fractional crystallisation and magma mixing can account for variations in major and trace element compositions, but they do not cause isotopic fractionation. Therefore, while both processes are relevant for the PVC [e.g. Schaaf et al. 2005], neither can explain the observed isotopic range by itself. However, crustal assimilation can introduce isotopic variability. To constrain the role of crustal assimilation at the PVC, the diverse suite of xenoliths collected from the PwA and Nealticán units is used to model assimilation-fractional crystallisation (AFC) processes after DePaolo [1981].

\subsection{Crustal assimilation modelling}

Geophysical evidence suggests a $40-50$ km thick continental crust beneath the PVC [Ferrari et al. 2012], comprised of Precambrian and Paleozoic terranes [OrtegaGutierrez et al. 1995; Ferrari et al. 2012], Mesozoic limestones, evaporites, shales and sandstones, and Tertiary terrigenous and volcanic rocks [Fries 1965; Goff et al. 1998; Siebe 2004; Schaaf et al. 2005; EspinasaPereña and Martín-Del Pozzo 2006; Siebe and Macías 2006; Sosa-Ceballos et al. 2014]. Despite the thick continental crust underlying the Central TMVB, crustal assimilation is widely considered negligible for the mantle-derived magmas of the region [e.g. MartínezSerrano et al. 2004; Straub et al. 2013; Cai et al. 2014; Straub et al. 2015]. Correlations of isotopic ratios with fractionation indices, which are typically attributed to AFC processes, have been described for high-Nb lavas of the SCVF [e.g. Straub et al. 2013]. However, these correlations have been interpreted to reflect addition of a silicic slab component to the mantle wedge rather than crustal assimilation [e.g. Straub et al. 2013; Straub et al. 2014; Straub et al. 2015; Cai et al. 2014]. On the other hand, the abundance of granodiorite, rhyolite, skarn and marble xenoliths in both pumices and lavas of the PVC (up to 55 vol.\% in the main PwA stage; Sosa-Ceballos et al. [2012]), some of which are partially digested, prompted the examination of potential crustal overprints in PVC magmas. Goff et al. [1998] and Goff et al. [2001] suggest carbonate and evaporite assimilation to account for elevated $\mathrm{CO}_{2}$ and $\mathrm{SO}_{2}$ degassing during present-day activity. Furthermore, the PVC's elevated ${ }^{87} \mathrm{Sr} /{ }^{86} \mathrm{Sr}$ ratios at similar ${ }^{143} \mathrm{Nd} /{ }^{144} \mathrm{Nd}$ ratios compared to the neighbouring SCVF high-Nb
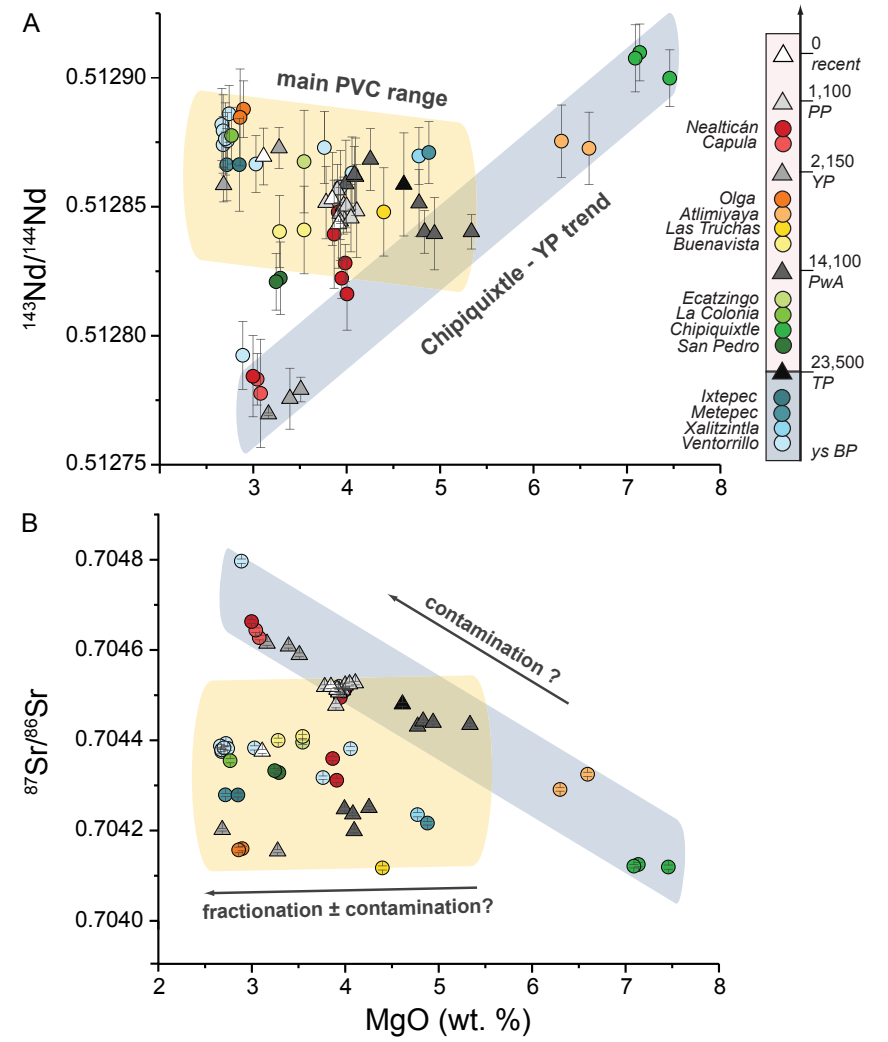

Figure 10: $[\mathrm{A}]{ }^{143} \mathrm{Nd} /{ }^{144} \mathrm{Nd}$ and $[\mathrm{B}]{ }^{87} \mathrm{Sr} /{ }^{86} \mathrm{Sr}$ vs. MgO. The yellow field highlights the main PVC range with no systematic variation in isotopic compositions. The blue field designates a subset of samples showing a correlation defined by the Chipiquixtle lava flow and the Yellow Pumice Plinian Eruption, referred to hereafter as the Chipiquixtle-YP trend. See text for further explanation.

lavas (Figure 5) have been interpreted to be caused by assimilation of local carbonates [Siebe 2004; Schaaf et al. 2005]. However, Sosa-Ceballos et al. [2014] rule out significant upper crustal assimilation at the PVC as their AFC models of skarn and sandstone assimilation fail to reproduce the compositional range of the PVC. They acknowledge that minor carbonate assimilation is likely, but argue that isotopic compositions are similarly enriched at Nevado de Toluca, which does not overlie shallow carbonates [Sosa-Ceballos et al. 2014]. Instead, they propose partial melting of variably sediment-modified mantle and subsequent assimilation of lower crustal rocks to explain the isotopic range of the PVC [Schaaf et al. 1994].

Variations of $\mathrm{Sr}$ and $\mathrm{Nd}$ isotopic compositions with $\mathrm{MgO}$ (Figure 10) reveal two distinct groups of samples. Most samples show no significant correlation of $\mathrm{Sr}-\mathrm{Nd}$ isotopic ratios with $\mathrm{MgO}$ (yellow field in Figure 10), representing the main PVC range defined in Figure 8. However, a subset of samples displays a linear correlation between $\mathrm{MgO}$ and $\mathrm{Sr}-\mathrm{Nd}$ isotopic compositions, with the Chipiquixtle flank eruption at the primitive end, and most YP pumices as well as the 
Capula flow, some Nealticán samples and one Ventorrillo lava at the evolved end (blue field in Figure 10). In addition, the Atlimiyaya flank eruption consistently forms part of the trend defined by Chipiquixtle-YP. Samples of the Chipiquixtle-YP trend overlap with the main PVC range for $\mathrm{MgO}$ concentrations of $4-5 \%$, and some units within this range cannot be unequivocally attributed to the one or the other group, including the PwA pumices (Figure 10). However, all the eruptions that exceed the main PVC range in Figure 10 form part of the Chipiquixtle-YP trend.

The correlation of isotopic ratios with fractionation indices displayed by the Chipiquixtle-YP trend has not previously been described for rocks of the PVC and suggests that geochemical variations are dominated by crustal contamination. To test whether assimilation of local crust can produce the ChipiquixtleYP trend, and to evaluate the role of crustal contamination in the main PVC range, a suite of xenoliths collected from the PVC (Table 1, Supplementary Data 1: Table S1.1) was used to model AFC processes after DePaolo [1981]. Assimilation-fractional crystallisation models were produced for $\mathrm{Sr}, \mathrm{Nd}$ and $\mathrm{Hf}$ isotopic ratios, $\mathrm{La} / \mathrm{Nb}$ ratios and $\mathrm{Mg}$ concentrations. The least evolved sample of the dataset, POP-95 (Chipiquixtle), was used as the magmatic endmember. A skarn (POP-97sk) and a Tertiary rhyolite (POP-97sst) xenolith sampled from the Nealticán lava were selected as shallow crustal assimilants (Table 1, Supplementary Data 1: Table S1.1), since alongside comagmatic granodiorites, these lithologies are the most common xenoliths in PVC lavas and pumices [Schaaf et al. 2005; Sosa-Ceballos et al. 2014]. To assess the prospect of lower crustal assimilation, central Mexican metasedimentary granulite sample JC 101 from Schaaf et al. [1994] was used. Since no Hf isotope data is available for JC 101, Hf isotopic ratios were modelled using metapelitic granulite sample OAX-5-86 Vervoort et al. [2000]. Modelling parameters are given in Table 2, and the results shown in Figure 11. Full models are given in Supplementary Data 2.

\subsubsection{Lower crustal assimilation}

Assimilation of lower crustal rocks can reproduce the Chipiquixtle-YP trend in major and trace element, and isotope-isotope space (blue line in Figure 11). Moderate crystallisation $(\sim 10-15 \%)$ at an assimilation rate three times lower than that of fractional crystallisation $(r=0.30)$ can reproduce the Chipiquixtle-YP compositional range. Minor discrepancies between the models and the data likely reflect the uncertainty related to the composition of the lower crustal endmember. The lower crust beneath Mexico is composed of a variety of igneous and metasedimentary rocks [Ruiz et al. 1988; Roberts and Ruiz 1989; Schaaf et al. 1994; Straub et al. 2015], and considerable compositional variation is expected. Since no constraints for the composition of
Table 2 - Endmembers and modelling parameters used for AFC modelling.

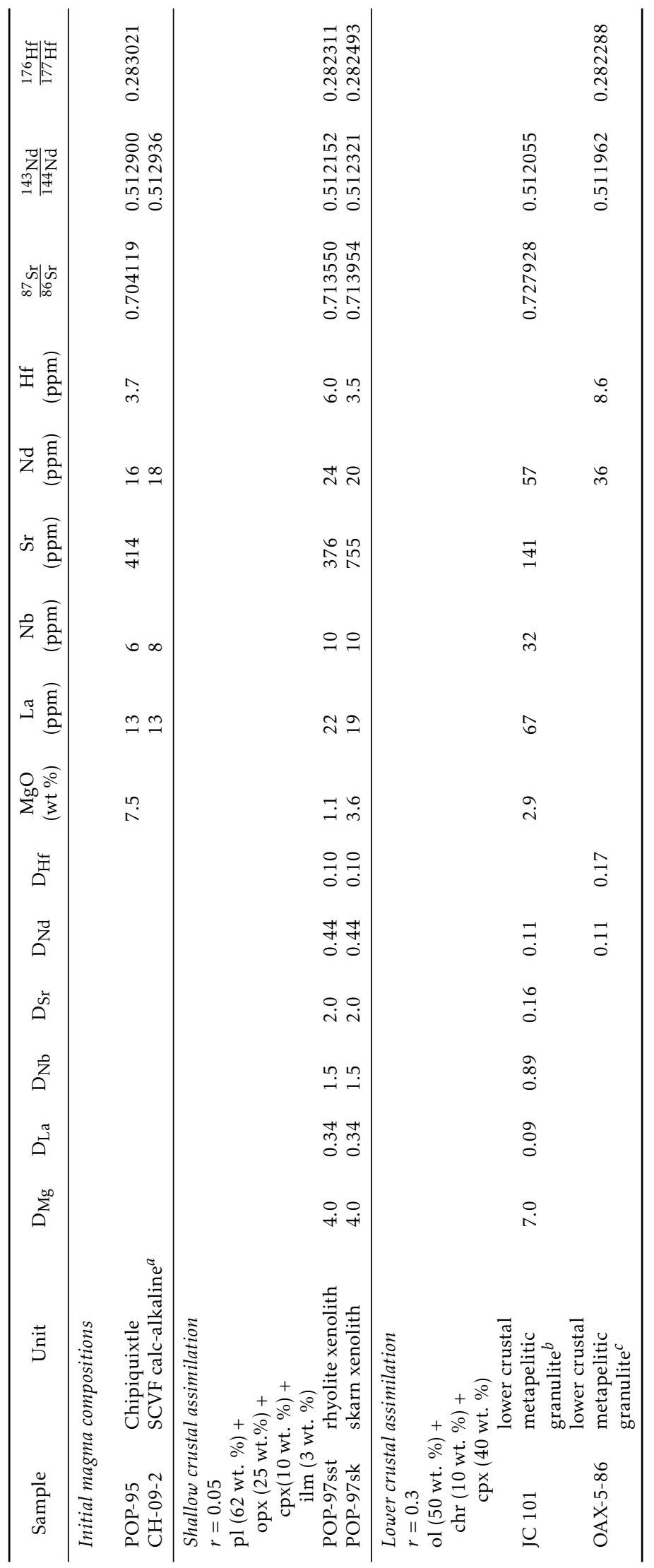

${ }^{a}$ from Straub et al. [2015]; ${ }^{b}$ from Schaaf et al. [1994]; ${ }^{c}$ from Vervoort et al. [2000].

$r$ = ratio of assimilation to crystal fractionation. $\mathrm{D}=$ Bulk distribution coefficients calculated for given shallow and lower crustal phenocryst assemblages from Luhr and Carmichael [1980], Mahood and Hildreth [1983],Fujimaki et al. [1984], Lemarchand et al. [1987], Bacon and Druitt [1988], Tourrette et al. [1991], Beattie [1994], Ewart and Griffin [1994], Bindeman and Davis [2000], Nielsen and Beard [2000], and Huang [2006]. 

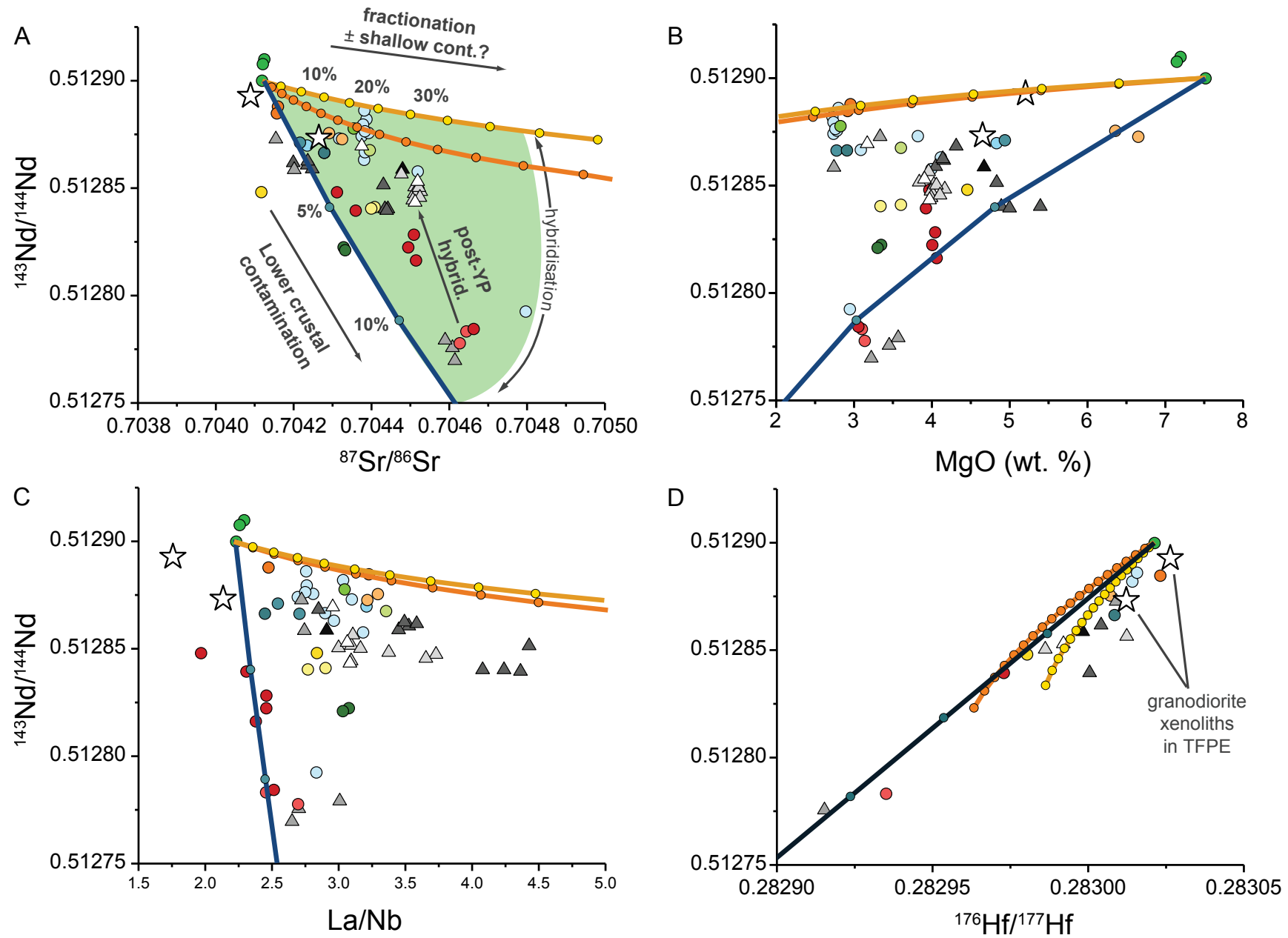

AFC mixing models

rhyolite xenolith in Nealticán lava (POP-97sst) $r=0.05 ; 5 \%$ crystallisation steps

[A] - [C]lower crustal granulite (JC 101, Schaaf et al., 1994) $r=0.30 ; 5 \%$ crystallisation steps [D] lower crustal granulite (OAX-5-86, Vervoort et al., 2000) $r=0.05 ; 5 \%$ crystallisation steps $r=0.30 ; 5 \%$ crystallisation steps

Figure 11: AFC models calculated for mixing of crustal components with the least evolved unit of the sample suite, Chipiquixtle. Four panels show ${ }^{143} \mathrm{Nd} /{ }^{144} \mathrm{Nd}$ vs $[\mathrm{A}]{ }^{87} \mathrm{Sr} /{ }^{86} \mathrm{Sr} ;[\mathrm{B}] \mathrm{MgO}$; [C] La/Nb; [D] ${ }^{176} \mathrm{Hf} /{ }^{177} \mathrm{Hf}$. See text for explanation.

the lower crust beneath the PVC are available, the central Mexican granulite JC 101 from Schaaf et al. [1994] used here for modelling of $\mathrm{Sr}-\mathrm{Nd}$ isotopic ratios, $\mathrm{Mg}$ and $\mathrm{La} / \mathrm{Nb}$ ratios (Table 2 ) is considered the best estimate for the lower crust beneath the central TMVB. The model produces a self-consistent explanation for major, trace and isotopic data at reasonable degrees of crystallisation. Magmas of the Chipiquixtle-YP trend are thus proposed to show lower crustal signatures, acquired in reservoirs of stalling magmas in the lower crust and/or during their ascent to the surface. Variable amounts of assimilation could be related to differences in the extent and timescale of exposure to the lower crust.

\subsubsection{Upper crustal assimilation}

The shallow crustal basement beneath the PVC is represented in the models by rhyolite and skarn xenoliths POP-97sst and POP-97sk. Modelling of 20-45 \% crystallisation at minimal assimilation rates $(r=0.05)$ produces trends that largely coincide with the compositional variation displayed by the main PVC range (yellow and orange lines in Figure 11). This implies that assimilation of shallow basement may indeed play a role in the late-stage petrogenesis of PVC rocks, potentially modifying whole rock geochemical characteristics of PVC lavas and pumices.

Granodioritic xenoliths show significant compositional overlap with the PVC andesites and dacites (stars in Figure 11), allowing for the assimilation of large quantities of granodioritic material without produc- 
ing any distinct geochemical variation. In accordance with Schaaf et al. [2005], such granodiorites are interpreted as comagmatic rocks representing solidified domains of the igneous body beneath the PVC, e.g. cool margins of magma reservoirs or wall rock in the conduit. The volumetric predominance of such granodiorites over other types of xenoliths in PVC rocks indicates that melt reservoirs in the shallow plumbing system are predominantly hosted in solidified comagmatic rocks rather than in rocks of the crustal basement, thus limiting the scope for PVC magmas to extensively assimilate country rock. Substantial assimilation of local basement might only occur in association with mafic injections into the system, when heat, melt and gas addition pressurises and remobilises the magma reservoir sufficiently to fracture and incorporate wall rock [e.g. Beard et al. 2005; Glazner 2007; Andrews et al. 2008; Huber et al. 2011]. Uptake of shallow crustal xenoliths by magmas en route to the surface is considered an additional important factor. Both processes imply pre-eruptive disaggregation and bulk assimilation as the dominant form of interaction between magmas and local basement, suggesting only a minor role for assimilation by melting of xenoliths. Field observations of $\mathrm{m}$-sized xenoliths in PVC rocks showing minimal evidence for digestion support this model (Appendix B).

The low $r$-value of 0.05 for the rhyolite and skarn assimilation models (Table 2; Figure 11) is consistent with the field evidence for limited interaction of PVC magmas with the surrounding country rocks. Assuming interaction with local basement is dominated by bulk assimilation rather than by melting, the modelled fractionation values shown in Figure 11 need to be considered semi-quantitative, since the AFC model of DePaolo [1981] does not strictly account for bulk assimilation. Instead, the models presented here illustrate that even minor shallow assimilation of local country rocks can explain some of the geochemical characteristics of the main PVC range. In fact, higher assimilation rates of carbonate rocks would result in silicaundersaturated magmas with exceedingly high $\mathrm{CaO}$ concentrations [Mollo et al. 2010; Di Rocco et al. 2012], which are not observed at the PVC.

Finally, the local upper crust is composed of a variety of lithologies, which have undergone variable degrees of contact metamorphism with the magma reservoirs feeding the PVC [Schaaf et al. 2005]. This is evident from the wide range of PVC xenolith compositions sampled by Schaaf et al. [2005], Sosa-Ceballos et al. [2014], and during this study. Constraints on whether crustal assimilation is a significant process rely heavily on the specific xenolith used and may lead to conflicting results. The dataset and models presented here demonstrate that limited assimilation of skarn and rhyolite xenoliths can reproduce key geochemical trends observed in PVC rocks, and shallow crustal assimilation is thus considered a significant process since at least $\sim 23.5 \mathrm{ka}$.

\subsection{Implications for the PVC plumbing system}

\subsubsection{Magma mixing}

Assimiliation-fractional crystallisation of PVC magmas in the lower and upper crust can explain the compositional range of PVC lavas and pumices (Figure 11). Geochemical variations over time (Figure 8) suggest that the PVC plumbing system hosts several magma reservoirs with distinct crustal signatures, which intermittently interact with each other. There is abundant petrological evidence for magma mixing and mingling at the PVC since at least $\sim 23.5 \mathrm{ka}$ and up to the presentday activity [e.g. Straub and Martín-Del Pozzo 2001; Martín-Del Pozzo et al. 2003; Schaaf et al. 2005; Witter et al. 2005; Sosa-Ceballos et al. 2014], and field observations confirm that even the compositionally most primitive Chipiquixtle flow features $\mathrm{mm}$ - to m-thick bands of intermingled melts (Appendix B). This suggests that all PVC magmas were subject to pre-eruptive mixing and mingling processes, and the whole rock chemistry of PVC lavas and pumices can be explained by the mixing of magmas with distinct crustal signatures, producing melts of hybrid compositions (green field in Figure 11). Indeed, samples of the YP Plinian eruption and the subsequent Capula and Nealticán effusive eruptions trace such a hybridisation process from lower crustal signatures (YP) to main PVC range characteristics (Nealticán and PP; Figure 11). With these considerations in mind, the architecture of the PVC plumbing system and its dynamics over the past $\sim 23.5 \mathrm{ka}$ are discussed below and represented schematically in Figure 12 .

\subsubsection{The shallow plumbing system}

Melt inclusion and vesicle size distributions point toward a network of conduits and interfingering dykes at shallow depths beneath the PVC [Atlas et al. 2006; Roberge et al. 2009; Cross et al. 2012]. Based on seismic velocity models, Kuznetsov and Koulakov [2014] suggest that the modern Popocatépetl edifice is made up of solidified magmatic rocks perforated by fluid- and melt-filled fractures, cracks and pores down to a depth of at least $4 \mathrm{~km}$ below present sea level (i.e. $\sim 9.5 \mathrm{~km}$ depth beneath the summit crater). This is supported by abundant granodiorite xenoliths in PVC rocks [SosaCeballos et al. 2012], which indicates the presence of a solidified comagmatic body hosting the active magma reservoir(s) [Schaaf et al. 2005]. It is proposed that this granodioritic body accumulated and increased in volume throughout the eruptive history of the PVC (dark grey in Figure 12). It could thus accommodate significant volumes of both crystal mush and eruptible magma in a dynamic, interconnected network, facilitating hybridisation between geochemically distinct magma batches (yellow/orange in Figure 12) and/or magma injections from deeper crustal levels (purple in 
Figure 12). The plumbing system beneath the PVC is thus envisioned as a network of transient melt reservoirs of varying compositions and crystal mush, hosted in a voluminous comagmatic body. This is consistent with emerging views of magma reservoirs as extensive, complex and highly dynamic systems of mush, melt and fluids rather than stagnant, stable magma 'chambers' [Christopher et al. 2015; Bachmann and Huber 2016; Druitt et al. 2016; Cashman et al. 2017; Magee et al. 2018; Pankhurst et al. 2018].

The upper crustal plumbing system described above is the locus of magma hybridisation at the PVC. Magma injections from lower crustal levels are suggested to feed the shallow plumbing system and mix with resident magma reservoirs, producing the hybrid melts of the 'main PVC range' that have dominated volcanism at the PVC since $>23.5 \mathrm{ka}$ (Figures 11 and 12A). Extensive magma mixing precludes detailed constraints on geochemical characteristics of the parental melts. However, the more primitive whole rock compositions of the Chipiquixtle and Atlimiyaya flank lavas suggest that magmas feeding these eruptions largely bypassed the shallow plumbing system and underwent limited hybridisation, as schematically shown for the Chipiquixtle eruption in Figure 12A.

\subsubsection{The primitive endmember}

The Chipiquixtle lava is the most primitive unit of the Popocatépetl edifice reported to date, and it may thus provide insights into the composition of parental melts of the PVC. Its whole rock composition is similar to some lavas of the neighbouring SCVF (Figure 13), and the general geochemical affinity of SCVF calc-alkaline rocks to the PVC at generally more primitive compositions (e.g. Figure 5) has prompted suggestions of a genetic relationship [Straub and Martín-Del Pozzo 2001; Schaaf et al. 2005]. More primitive compositions of the monogenetic SCVF magmas (i.e. basalts and basaltic andesites) may be related to shorter crustal residence times compared to PVC magmas. Indeed, prolonged crustal residence of SCVF magmas would facilitate crustal assimilation, which could produce melt compositions similar to PVC rocks (Figure 13). AFC modelling using a calc-alkaline SCVF andesite as the magmatic endmember (CH-09-2: Straub et al. [2015]), and crustal assimilants and parameters identical to the models shown in Figure 11, can reproduce the vectors of both the Chipiquixtle-YP array and the main PVC range (Figure 13). This supports a genetic relationship between calc-alkaline SCVF and PVC rocks, and we suggest that primitive calc-alkaline rocks erupted in the SCVF approximate the parental melts feeding the PVC plumbing system. While such magmas pass through the crust rapidly and with little modification in the SCVF [e.g. Straub et al. 2013; Straub et al. 2015], they are significantly overprinted by AFC and hybridisation processes in the complex plumbing system be- neath the PVC (Figures 10-13).

\subsubsection{An eruptive record dominated by magma hy- bridisation}

The YP Plinian eruption and subsequent effusive eruptions illustrate the interplay of crustal assimilation at variable depths and magma hybridisation that dominates PVC whole rock compositions. Magmas stalling and fractionating at lower crustal levels are predicted to show evolved compositions coupled with lower crustal signatures (Figure 10). A magma with such characteristics was tapped during the YP Plinian eruption (Figure 8), and its lower crustal signatures continue to manifest during the subsequent Capula and Nealticán flank eruptions. However, the Nealticán lavas trace the waning influence of the lower crustal signature magma in a gradual hybridisation process with a 'main PVC range' magma, which eventually results in the eruption of main PVC range compositions during the PP Plinian eruption at $\sim 1100$ a BP (Figures $8,10,11$ and 12C).

Hybridisation between deep-seated magmas and melts of the upper crustal plumbing system appears to largely buffer compositions of the main PVC range. However, subtle compositional differences are preserved within the shallow plumbing system, as shown by the two-stage PwA Plinian eruption (Figures 9 and $12 \mathrm{~B})$. Both phases erupted pumices with hybrid crustal signatures (green field in Figure 11) representative of the main PVC range (Figure 8), however they show systematic compositional differences (Figure 9). This indicates that both magmas involved in the eruption were shallow hybrids of slightly different compositions (Figure 12B), which were mingled during the transition from the initial to the main stage of the PwA [Sosa-Ceballos et al. 2012]. Whole rock geochemical data further suggest that the PwA Plinian eruption caused a long-lasting change in the configuration of the shallow plumbing system: The shallow evolved reservoir primarily feeding pre-PwA lavas was largely exhausted during the PwA, and post-PwA effusive eruptions were dominated by the second reservoir tapped during the PwA Plinian eruption (Figures 8, 9 and 12). A significant impact on the plumbing system is consistent with the inferred magnitude of the PwA. With a volume of $1.8 \mathrm{~km}^{3}$ DRE [Siebe et al. 2017], it is the largest eruption recorded at the PVC, which requires large portions of the plumbing system to be remobilised and tapped during the event. Furthermore, the high energy release resulted in significant fracturing and uptake of wall rock (Figure 12B), as evidenced by the abundance of xenoliths in the deposits of the main stage of the PwA eruption (up to 56 vol.\%; SosaCeballos et al. [2012]).

In summary, as shown graphically in Figure 11, the interplay of crustal assimilation at various depths on the one hand, and hybridisation between shallow 


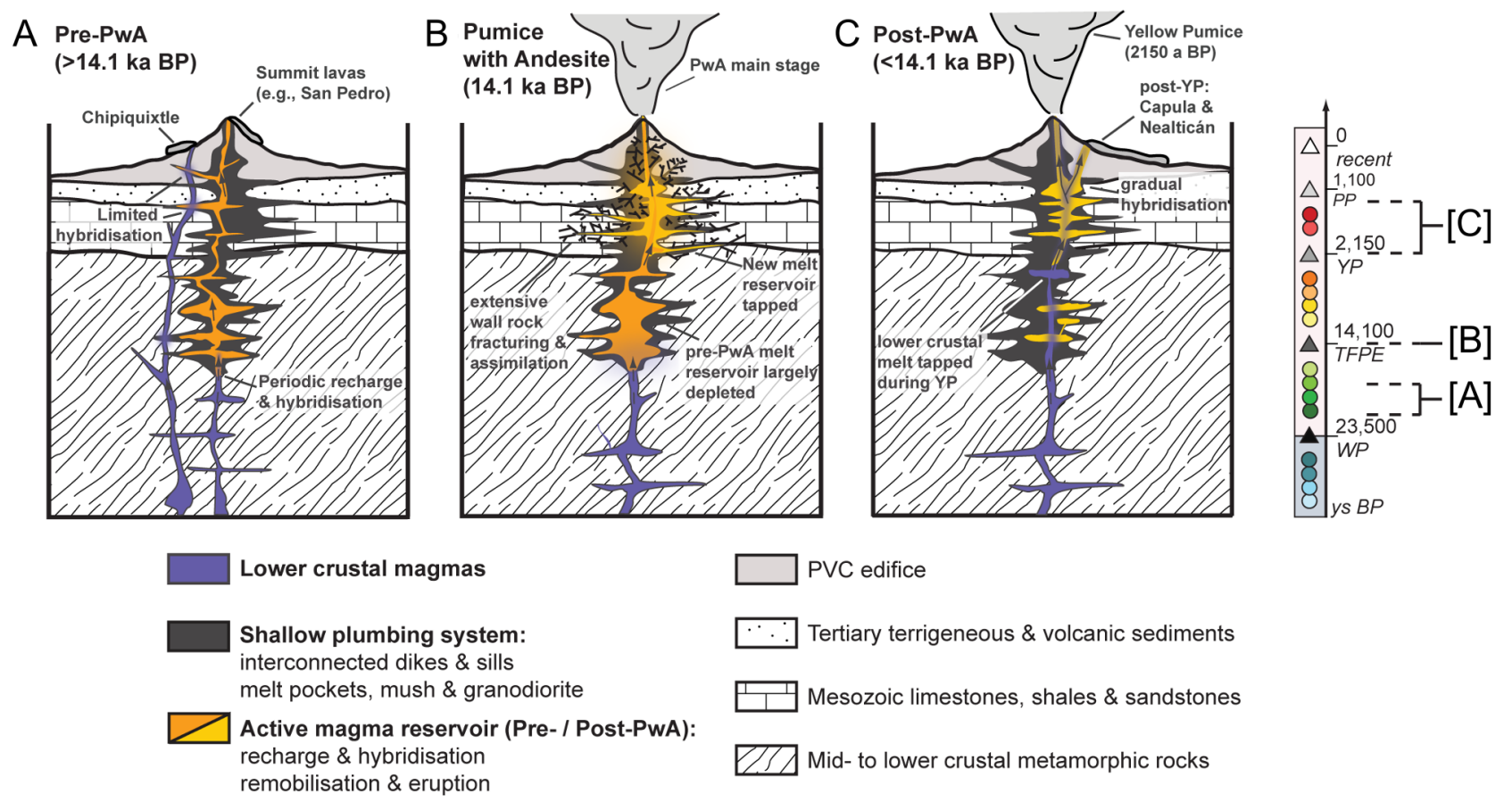

Figure 12: Schematic model of the evolution of the plumbing system of Popocatépetl volcano. [A] Pre-Pumice with Andesite (PwA, $14.1 \mathrm{ka} \mathrm{BP})$. Periodic recharge of the main shallow magmatic body with lower crustal melts remobilises crystal mush and produces hybrid magmas erupting as summit lavas (e.g. San Pedro). In contrast, lower crustal melts largely circumventing the shallow magmatic body reach the surface after limited shallow hybridisation and thus preserve distinct compositions (e.g. Chipiquixtle). [B] The Pumice with Andesite eruption. The magma reservoir active previous to the PwA eruption is largely depleted during the initial stage of the PwA. A new shallow melt reservoir is tapped, associated with major wall rock fracturing, producing the explosive climax of the PwA main stage. [C] Post-PwA configuration, focussing on the Yellow Pumice Plinian Eruption (YP, 2150 a BP) and subsequent effusive eruptions. Lower crustal recharge triggers YP eruption, and lower crustal magmas are erupted in the late stage of the YP and during the subsequent Capula effusive flank eruption. Lavas of the Nealticán flank eruption record the waning influence of the lower crustal melt, sampling gradual hybridisation with shallow magma, which results in the buffered compositions of the main PVC range.

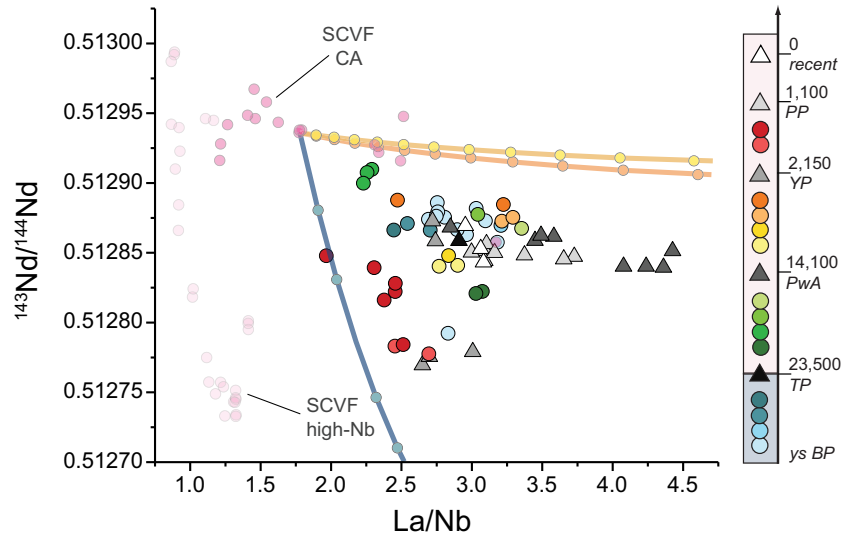

Figure 13: ${ }^{143} \mathrm{Nd} /{ }^{144} \mathrm{Nd}$ vs. La/Nb for Popocatépetl and Ventorrillo samples, with calc-alkaline and high$\mathrm{Nb}$ suites from the SCVF [Straub et al. 2015] for comparison. AFC model calculated using calc-alkaline SCVF sample CH-09-2 with same assimilants and parameters as in Figure 11A-C. See text for explanation. stalling reservoirs and fresh injections on the other hand, can reproduce the entire range of compositions displayed by PVC lavas and pumices. The long-lived upper crustal plumbing system beneath the PVC produced a voluminous environment of solidified comagmatic rocks hosting distinct, interconnected melt reservoirs. This facilitates extensive magma hybridisation within the shallow plumbing system, which buffers most compositions erupted by the PVC. Hybridisation textures found in present-day samples [e.g. Straub and Martín-Del Pozzo 2001; Schaaf et al. 2005; Witter et al. 2005; Roberge et al. 2009] and compositional variability exceeding the range displayed by pumices and lavas erupted in more than $23.5 \mathrm{ka}$ (Figures 3-5), suggest similar dynamics for the present-day plumbing system of the PVC.

\section{Conclusions}

Research on active stratovolcanoes tends to be focussed on present-day activity and past cataclysmic eruptions, 
while past effusive and minor explosive eruptions are often neglected. This results in an incomplete understanding of volcanic systems and their dynamics, as Plinian eruptions merely provide isolated snapshots in time that lack potentially crucial information about their cause and effects on the plumbing system. Here, we present a comprehensive geochemical study of effusive and explosive eruptions of the last $\sim 23.5 \mathrm{ka}$ at the $\mathrm{PVC}$, to highlight mantle source characteristics, reconstruct the evolution and dynamics of the plumbing system, and show that the compositional range of the PVC rock suite is dominated by crustal processes such as assimilation-fractional crystallisation and magma mixing.

PVC magmas originate from a mantle source depleted by multiple melting events and modified by addition of subducted sediment and/or eroded forearc granodiorites. The PVC rock suite shows a restricted range for major and trace element, and $\mathrm{Sr}-\mathrm{Nd}-$ Hf isotope compositions, with no long-term geochemical trends or systematic changes leading up to Plinian eruptions. Secondary geochemical variability of lavas and pumices reflects the evolution and dynamics of the plumbing system in the past $\sim 23.5 \mathrm{ka}$ : The sector collapse of the Ventorrillo edifice and the associated VEI 5 TP Plinian eruption $\sim 23.5 \mathrm{ka}$ BP had no significant effect on the plumbing system of the PVC, as indicated by unchanged magma compositions. During the VEI 6 PwA Plinian eruption $14.1 \mathrm{ka} B P$, the hitherto dominant magma reservoir was exhausted, and a new, geochemically distinct melt domain was tapped. After the PwA eruption, the plumbing system remained relatively steady until $\sim 2150$ a BP, when the VEI 6 YP Plinian eruption tapped a magma reservoir with lower crustal signatures. The subsequent Capula and Nealticán effusive eruptions record a gradual hybridisation, which resulted in the reset to average PVC compositions for the VEI 4 PP Plinian eruption $\sim 1100$ a BP. Throughout the past $\sim 23.5 \mathrm{ka}$ BP, effusive flank eruptions produced more primitive magmas from deeper reservoirs, which experienced limited hybridisation by circumventing the shallow plumbing system.

The compositional range of lavas and pumices erupted at the PVC is the result of crustal processes rather than mantle source heterogeneity. Shallow fractional crystallisation and limited assimilation of local upper crustal host rocks (e.g. skarn and older volcanics) can account for the main compositional range defining most PVC rocks. In addition, lower crustal assimilation can explain the distinct geochemical characteristics displayed by some pumices of the YP Plinian eruption $\sim 2150$ a BP and by several effusive flank eruptions. Geochemical data and textural observations suggest that such geochemically distinct magmas undergo extensive mixing and mingling in the shallow plumbing system. All PVC magmas are subject to pre-eruptive hybridisation processes, albeit to different degrees. The relatively narrow compositional range of the majority of PVC rocks indicates a high degree of hybridisation. This illustrates the efficiency with which a volumetrically dominant, long-lived plumbing system such as beneath the PVC can buffer magma compositions through AFC processes combined with hybridisation between shallow stalling reservoirs and fresh injections.

\section{ACKNOWLedgements}

This work has been made possible by a Janet Watson $\mathrm{PhD}$ studentship to MFM from the department of Earth Science and Engineering at Imperial College London. We would like to thank Stanislav Strekopytov, Emma Humphreys-Williams and Sam Hammond for trace element analyses. Special thanks to Katharina Kreissig and Barry Coles for their assistance in the clean laboratories and the mass spectrometers at the MAGIC laboratories at Imperial College London. Feixiang Wei and Evelyn Baker are thanked for their efforts with Hf isotope set up and processing at Imperial. Chetan Nathwani, Samuel Hill, Nicole Allen, Frey Fife are thanked for their help powdering samples. The work was financially supported by NERC grant NE/M014584 to CMP, and by Royal Society-Newton Fund International Exchanges Grant IE1 40605 to CMP. We are grateful for the constructive reviews of Julia Crummy and Silvio Mollo, and for the editorial handling of Jamie Farquharson.

\section{Author contributions}

Sampling for this study was conducted by MM, CMP and JP with guidance of HDG and GG. MM and GG established the geological map and eruptive history. MM produced isotope and trace element data under the supervision of JP. All authors contributed to discussions and writing of the manuscript.

\section{Data AVAilability}

Data are provided in Appendix A and Appendix B, and in the supplementary data provided online alongside this article (Supplementary Data 1 and Supplementary Data 2).

\section{COPYRIGHT NOTICE}

(c) The Author(s) 2019. This article is distributed under the terms of the Creative Commons Attribution 4.0 International License, which permits unrestricted use, distribution, and reproduction in any medium, provided you give appropriate credit to the original author(s) and the source, provide a link to the Creative Commons license, and indicate if changes were made. 


\section{REFERENCES}

Adams, N. K., B. F. Houghton, S. A. Fagents, and W. Hildreth (2006). "The transition from explosive to effusive eruptive regime: The example of the 1912 Novarupta eruption, Alaska". Geological Society of America Bulletin 118.5-6, pp. 620-634. DoI: 10.1130/ b25768. 1.

Andrews, B. J., J. E. Gardner, and T. B. Housh (2008). "Repeated recharge, assimilation, and hybridization in magmas erupted from El Chichón as recorded by plagioclase and amphibole phenocrysts". Journal of Volcanology and Geothermal Research 175.4, pp. 415426. Dor: 10.1016/ j . jvolgeores.2008.02.017.

Arana-Salinas, L., C. Siebe, and J. L. Macías (2010). "Dynamics of the ca. 4965yr 14C BP "Ochre Pumice" Plinian eruption of Popocatépetl volcano, México". Journal of Volcanology and Geothermal Research 192.34, pp. 212-231. DoI: 10.1016/ j . jvolgeores. 2010. 02.022.

Atlas, Z. D., J. E. Dixon, G. Sen, M. Finny, and A. L. Martín-Del Pozzo (2006). "Melt inclusions from Volcán Popocatépetl and Volcán de Colima, Mexico: Melt evolution due to vapor-saturated crystallization during ascent". Journal of Volcanology and Geothermal Research 153.3-4, pp. 221-240. DoI: 10 . 1016 / j . jvolgeores.2005.06.010.

Bachmann, O. and C. Huber (2016). "Silicic magma reservoirs in the Earth's crust". American Mineralogist 101.11, pp. 2377-2404. Dor: $10.2138 /$ am-20165675.

Bacon, C. R. and T. H. Druitt (1988). "Compositional evolution of the zoned calcalkaline magma chamber of Mount Mazama, Crater Lake, Oregon”. Contributions to Mineralogy and Petrology 98.2, pp. 224-256. DOI: 10.1007 / bf00402114.

Bast, R., E. E. Scherer, P. Sprung, M. Fischer-Gödde, A. Stracke, and K. Mezger (2015). "A rapid and efficient ion-exchange chromatography for Lu-Hf, $\mathrm{Sm}-\mathrm{Nd}$, and $\mathrm{Rb}-\mathrm{Sr}$ geochronology and the routine isotope analysis of sub-ng amounts of Hf by MC-ICPMS". Journal of Analytical Atomic Spectrometry 30.11, pp. 2323-2333. Dor: 10.1039/ c5 ja00283d.

Beard, J. S., P. C. Ragland, and M. L. Crawford (2005). "Reactive bulk assimilation: A model for crustmantle mixing in silicic magmas". Geology 33.8, p. 681. DoI: 10.1130/g21470.1.

Beattie, P. (1994). "Systematics and energetics of traceelement partitioning between olivine and silicate melts: Implications for the nature of mineral/melt partitioning". Chemical Geology 117.1-4, pp. 57-71. DoI: $10.1016 / 0009-2541$ ( 94 ) $90121-x$.

Bindeman, I. N. and A. M. Davis (2000). "Trace element partitioning between plagioclase and melt: investigation of dopant influence on partition behavior". Geochimica et Cosmochimica Acta 64.16, pp. 28632878. DoI: 10 . 1016/s0016-7037 (00)00389-6.
Bonasia, R., C. Scaini, L. Capra, M. Nathenson, C. Siebe, L. Arana-Salinas, and A. Folch (2013). "Longrange hazard assessment of volcanic ash dispersal for a Plinian eruptive scenario at Popocatépetl volcano (Mexico): implications for civil aviation safety". Bulletin of Volcanology 76.1. DoI: 10.1007/ s00445-0130789-z.

Bouvier, A., J. D. Vervoort, and P. J. Patchett (2008). "The Lu-Hf and Sm-Nd isotopic composition of CHUR: Constraints from unequilibrated chondrites and implications for the bulk composition of terrestrial planets". Earth and Planetary Science Letters 273.1-2, pp. 48-57. Dor: 10 . 1016 / j . epsl . 2008. 06.010.

Boudal, C. and C. Robin (1988). "Relations entre dynamismes éruptifs et réalimentations magmatiques d'origine profonde au Popocatépetl". Canadian Journal of Earth Sciences 25.7, pp. 955-971. Dor: 10 . 1139/ e88-096.

Cadoux, A., Y. Missenard, R. G. Martinez-Serrano, and H. Guillou (2011). "Trenchward Plio-Quaternary volcanism migration in the Trans-Mexican Volcanic Belt: the case of the Sierra Nevada range". Geological Magazine 148.03, pp. 492-506. Dor: 10 . 1017 / s0016756810000993.

Cai, Y., A. LaGatta, S. L. Goldstein, C. H. Langmuir, A. Gómez-Tuena, A. L. Martín-Del Pozzo, and G. Carrasco-Núñez (2014). "Hafnium isotope evidence for slab melt contributions in the Central Mexican Volcanic Belt and implications for slab melting in hot and cold slab arcs". Chemical Geology 377, pp. 45-55. Dor: $10.1016 / \mathrm{j}$. chemgeo.2014.04.002.

Castro, J. M. and J. E. Gardner (2008). "Did magma ascent rate control the explosive-effusive transition at the Inyo volcanic chain, California". Geology 36.4, p. 279. DOI: $10.1130 / \mathrm{g} 24453 \mathrm{a} .1$.

Cashman, K. V., R. S. J. Sparks, and J. D. Blundy (2017). "Vertically extensive and unstable magmatic systems: A unified view of igneous processes". Science 355.6331, eaag3055. Dor: 10.1126/science . aag3055.

Christopher, T. E., J. Blundy, K. Cashman, P. Cole, M. Edmonds, P. J. Smith, R. S. J. Sparks, and A. Stinton (2015). "Crustal-scale degassing due to magma system destabilization and magma-gas decoupling at Soufrière Hills Volcano, Montserrat". Geochemistry, Geophysics, Geosystems 16.9, pp. 2797-2811. Dor: 10 . $1002 / 2015 \mathrm{gc} 005791$.

Conte, G., J. Urrutia-Fucugauchi, A. Goguitchaichvili, A. M. Soler-Arechalde, O. Morton-Bermea, and A. Incoronato (2004). "Paleomagnetic Study of Lavas from the Popocatepetl Volcanic Region, Central Mexico". International Geology Review 46.3, pp. 210-225. DoI: 10.2747/0020-6814.46.3.210.

Cross, J., J. Roberge, and D. Jerram (2012). "Constraining the degassing processes of Popocatépetl Volcano, Mexico: A vesicle size distribution and glass geochemistry study". Journal of Volcanology and Geother- 
mal Research 225-226, pp. 81-95. DOI: 10 . $1016 /$ j . jvolgeores.2012.02.013.

Crummy, J. M., I. P. Savov, C. Navarro-Ochoa, D. J. Morgan, and M. Wilson (2014). "High-K Mafic Plinian Eruptions of Volcán de Colima, Mexico". Journal of Petrology 55.11, pp. 2155-2192. DOI: 10 . 1093 / petrology/egu053.

Davidson, J., S. De Silva, et al. (2000). "Composite volcanoes". Encyclopedia of volcanoes. Ed. by B. Houghton, H. Rymer, S. McNutt, and J. Stix. Vol. 1. Academic Press San Diego, CA, pp. 663-681.

De Astis, G., A. Peccerillo, P. D. Kempton, L. La Volpe, and T. W. Wu (2000). "Transition from calcalkaline to potassium-rich magmatism in subduction environments: geochemical and $\mathrm{Sr}, \mathrm{Nd}, \mathrm{Pb}$ isotopic constraints from the island of Vulcano (Aeolian arc)". Contributions to Mineralogy and Petrology 139.6, pp. 684-703. Dor: 10.1007/s004100000172.

De Maisonneuve, C. B., M. A. Dungan, O. Bachmann, and A. Burgisser (2012). "Petrological Insights into Shifts in Eruptive Styles at Volcán Llaima (Chile)". Journal of Petrology 54.2, pp. 393-420. Dor: 10.1093/ petrology/egs073.

Degruyter, W., O. Bachmann, A. Burgisser, and M. Manga (2012). "The effects of outgassing on the transition between effusive and explosive silicic eruptions". Earth and Planetary Science Letters 349-350, pp. 161-170. Dor: 10.1016/ j .epsl.2012.06.056.

Delgado-Granados, H., L. C. González, and N. P. Sánchez (2001). "Sulfur dioxide emissions from Popocatépetl volcano (Mexico): case study of a highemission rate, passively degassing erupting volcano". Journal of Volcanology and Geothermal Research 108.14, pp. 107-120. Dor: 10 . 1016 / s0377-0273(00) 00280-8.

DePaolo, D. J. (1981). "Trace element and isotopic effects of combined wallrock assimilation and fractional crystallization". Earth and Planetary Science Letters 53.2, pp. 189-202. DoI: 10 . $1016 / 0012$ $821 \times(81) 90153-9$.

Di Rocco, T., C. Freda, M. Gaeta, S. Mollo, and L. Dallai (2012). "Magma Chambers Emplaced in Carbonate Substrate: Petrogenesis of Skarn and Cumulate Rocks and Implications for CO2 Degassing in Volcanic Areas". Journal of Petrology 53.11, pp. 2307-2332. Dor: 10. 1093 / petrology/egs051.

Dingwell, D. B. (1996). "Volcanic Dilemma-Flow or Blow?" Science 273.5278, pp. 1054-1055. DoI: 10 . 1126 / science.273.5278. 1054.

Druitt, T. H., M. Mercier, L. Florentin, E. Deloule, N. Cluzel, T. Flaherty, E. Médard, and A. Cadoux (2016). "Magma Storage and Extraction Associated with Plinian and Interplinian Activity at Santorini Caldera (Greece)". Journal of Petrology 57.3, pp. 461494. DoI: 10.1093/petrology/egw015.

Edmonds, M. and R. A. Herd (2007). "A volcanic degassing event at the explosive-effusive transition".
Geophysical Research Letters 34.21. DoI: 10 . 1029 / 2007 gl031379.

Elliott, T. (2003). "Tracers of the slab". Inside the Subduction Factory. American Geophysical Union, pp. 23-45. DoI: 10.1029/138gm03.

Espinasa-Pereña, R. and A. L. Martín-Del Pozzo (2006). "Morphostratigraphic evolution of Popocatépetl volcano, México”. Special Paper 402: Neogene-Quaternary Continental Margin Volcanism: A perspective from México. Geological Society of America, pp. 115-137. Dor: 10.1130/2006.2402(05).

Ewart, A. and W. Griffin (1994). "Application of protonmicroprobe data to trace-element partitioning in volcanic rocks". Chemical Geology 117.1-4, pp. 251-284. DoI: 10. 1016/0009-2541(94)90131-7.

Fabbro, G. N., T. H. Druitt, and S. Scaillet (2013). "Evolution of the crustal magma plumbing system during the build-up to the 22-ka caldera-forming eruption of Santorini (Greece)". Bulletin of Volcanology 75.12. DoI: 10. 1007/s00445-013-0767-5.

Ferrari, L., C. M. Petrone, and L. Francalanci (2001). "Generation of oceanic-island basalt-type volcanism in the western Trans-Mexican volcanic belt by slab rollback, asthenosphere infiltration, and variable flux melting". Geology 29.6, p. 507. Dor: 10.1130/00917613 ( 2001) 029<0507: gooibt>2.0.co; 2 .

Ferrari, L., T. Orozco-Esquivel, V. Manea, and M. Manea (2012). "The dynamic history of the Trans-Mexican Volcanic Belt and the Mexico subduction zone". Tectonophysics 522-523, pp. 122-149. Dor: 10 . 1016/ j. tecto.2011.09.018.

Ferrat, M., D. J. Weiss, and S. Strekopytov (2012). “A single procedure for the accurate and precise quantification of the rare earth elements, Sc, Y, Th and $\mathrm{Pb}$ in dust and peat for provenance tracing in climate and environmental studies". Talanta 93, pp. 415-423. DoI: $10.1016 /$ j . talanta.2012.01.052.

Ferrari, L. (2004). "Slab detachment control on mafic volcanic pulse and mantle heterogeneity in central Mexico". Geology 32.1, p. 77. DoI: 10.1130/g19887.1.

Francalanci, L., P. Manetti, and A. Peccerillo (1989). "Volcanological and magmatological evolution of Stromboli volcano (Aeolian Islands): The roles of fractional crystallization, magma mixing, crustal contamination and source heterogeneity". Bulletin of Volcanology 51.5, pp. 355-378. DOI: 10 . 1007 / bf01056897.

Fries, C. (1965). “Geologia de la Hoja Cuernavaca, Estados de Morelos, México, Guerrero y Puebla". Instituto de Geofisica, Universidad Nacional Autónoma de México. Carta Geológica de México, scale 1.100, p. 000. Fujimaki, H., M. Tatsumoto, and K.-i. Aoki (1984). "Partition coefficients of $\mathrm{Hf}, \mathrm{Zr}$, and ree between phenocrysts and groundmasses". Journal of Geophysical Research 89.S02, B662. DOI: 10 . 1029 / jb089is02p0b662. 
Glazner, A. F. (2007). "Thermal limitations on incorporation of wall rock into magma”. Geology 35.4, p. 319. DoI: $10.1130 / \mathrm{g} 23134 \mathrm{a} .1$.

Goff, F., S. P. Love, R. Warren, D. Counce, J. Obenholzner, C. Siebe, and S. C. Schmidt (2001). "Passive infrared remote sensing evidence for large, intermittent CO2 emissions at Popocatépetl volcano, Mexico". Chemical Geology 177.1-2, pp. 133-156. DoI: 10. 1016/s0009-2541(00)00387-9.

Goff, F., C. J. Janik, H. Delgado, C. Werner, D. Counce, J. A. Stimac, C. Siebe, S. P. Love, S. N. Williams, T. Fischer, and L. Johnson (1998). Geological Society of America Bulletin 110.6, p. 0695. DoI: $10.1130 / 0016-$ 7606 ( 1998 ) 110<0695: gsomva>2.3. co;2.

Gomez-Tuena, A., C. H. Langmuir, S. L. Goldstein, S. M. Straub, and F. Ortega-Gutierrez (2006). "Geochemical Evidence for Slab Melting in the Trans-Mexican Volcanic Belt". Journal of Petrology 48.3, pp. 537-562. Dor: $10.1093 /$ petrology / egl071.

Gómez-Vazquez, A., S. D. la Cruz-Reyna, and A. T. Mendoza-Rosas (2016). "The ongoing dome emplacement and destruction cyclic process at Popocatépetl volcano, Central Mexico". Bulletin of Volcanology 78.9. Dor: 10. 1007 / s00445-016-1054-z.

Gonnermann, H. M. and M. Manga (2003). "Explosive volcanism may not be an inevitable consequence of magma fragmentation". Nature 426.6965, pp. 432435. Dor: $10.1038 /$ nature02138.

Hernández-Pineda, G. A., L. A. Solari, A. Gómez-Tuena, D. L. Méndez-Cárdenas, and O. Pérez-Arvizu (2011). "Petrogenesis and thermobarometry of the $\sim 50 \mathrm{Ma}$ rapakivi granite-syenite Acapulco intrusive: Implications for post-Laramide magmatism in southern Mexico". Geosphere 7.6, pp. 1419-1438. DoI: 10 . 1130 /ges00744. 1.

Horwitz, E. P., R. Chiarizia, and M. L. Dietz (1992). "A novel Strontium-selective extraction chromatographic resin". Solvent Extraction and Ion Exchange 10.2, pp. 313-336. Dor: 10 . 1080 / 07366299208918107.

Huang, F. (2006). "Effect of melt structure on traceelement partitioning between clinopyroxene and silicic, alkaline, aluminous melts". American Mineralogist 91.8-9, pp. 1385-1400. DoI: 10.2138/am . 2006 . 1909.

Huber, C., O. Bachmann, and J. Dufek (2011). "Thermo-mechanical reactivation of locked crystal mushes: Melting-induced internal fracturing and assimilation processes in magmas". Earth and Planetary Science Letters 304.3-4, pp. 443-454. DoI: 10 . 1016 / j.eps 1.2011.02.022.

Koleszar, A. M., A. J. Kent, P. J. Wallace, and W. E. Scott (2012). "Controls on long-term low explosivity at andesitic arc volcanoes: Insights from Mount Hood, Oregon". Journal of Volcanology and Geothermal Research 219-220, pp. 1-14. Dor: 10 . 1016 / j . jvolgeores.2012.01.003.
Kuznetsov, P. and I. Y. Koulakov (2014). "The threedimensional structure beneath the Popocatépetl volcano (Mexico) based on local earthquake seismic tomography". Journal of Volcanology and Geothermal Research 276, pp. 10-21. Dor: 10.1016/ j . jvolgeores . 2014.02 .017$.

Larocque, A. C., J. A. Stimac, C. Siebe, K. Greengrass, R. Chapman, and S. R. Mejia (2008). "Deposition of a high-sulfidation Au assemblage from a magmatic volatile phase, Volcán Popocatépetl, Mexico". Journal of Volcanology and Geothermal Research 170.1-2, pp. 51-60. Dor: $10.1016 /$ j . jvolgeores . 2007.09 . 009.

Le Bas, M. J., R. W. L. Maitre, A. Streckeisen, and B. Zanettin (1986). "A Chemical Classification of Volcanic Rocks Based on the Total Alkali-Silica Diagram". Journal of Petrology 27.3, pp. 745-750. Dor: 10.1093/petrology/27.3.745.

Lemarchand, F., B. Villemant, and G. Calas (1987). "Trace element distribution coefficients in alkaline series". Geochimica et Cosmochimica Acta 51.5, pp. 1071-1081. DoI: 10 . 1016/0016-7037 (87) 902018.

Luhr, J. F. and I. S. E. Carmichael (1980). "The Colima Volcanic complex, Mexico". Contributions to Mineralogy and Petrology 71.4, pp. 343-372. Dor: $10.1007 /$ bf 00374707.

Luhr, J. F. (1997). "Extensional tectonics and the diverse primitive volcanic rocks in the western Mexican volcanic belt". The Canadian Mineralogist 35.2, pp. 473-500. IssN: 0008-4476. eprint: https : / / pubs . geoscienceworld . org / canmin / article pdf / 35/2/473/4006330/473 \_35 \_2\_cm.pdf.

Macías, J. L. and C. Siebe (2005). "Popocatépetl's crater filled to the brim: significance for hazard evaluation". Journal of Volcanology and Geothermal Research 141.3-4, pp. 327-330. DoI: 10 . $1016 / \mathrm{j}$. jvolgeores.2004.10.005.

Magee, C. et al. (2018). "Magma Plumbing Systems: A Geophysical Perspective". Journal of Petrology 59.6, pp. 1217-1251. Dor: 10.1093/petrology/egy064.

Mahood, G. and W. Hildreth (1983). "Large partition coefficients for trace elements in high-silica rhyolites". Geochimica et Cosmochimica Acta 47.1, pp. 1130. DoI: 10.1016/0016-7037 (83)90087-x.

Martín-Del Pozzo, A., G. Cifuentes-Nava, E. CabralCano, G. S. M. Reyes, A. Martínez-Bringas, E. Garcia, and C. Arango-Galvan (2002). "Volcanomagnetic signals during the recent Popocatépetl (México) eruptions and their relation to eruptive activity". Journal of Volcanology and Geothermal Research 113.3-4, pp. 415-428. DoI: 10.1016/s0377-0273 (01) 00275$\mathrm{x}$.

Martín-Del Pozzo, A., G. Cifuentes, E. Cabral-Cano, R. Bonifaz, F. Correa, and I. Mendiola (2003). "Timing magma ascent at Popocatepetl Volcano, Mexico, 2000-2001". Journal of Volcanology and Geothermal 
Research 125.1-2, pp. 107-120. Dor: 10.1016/s03770273 ( 03 ) $00091-x$.

Martínez-Serrano, R. G., P. Schaaf, G. Solís-Pichardo, M. del Sol Hernández-Bernal, T. Hernández-Treviño, J. J. Morales-Contreras, and J. L. Macías (2004). "Sr, $\mathrm{Nd}$ and $\mathrm{Pb}$ isotope and geochemical data from the Quaternary Nevado de Toluca volcano, a source of recent adakitic magmatism, and the Tenango Volcanic Field, Mexico". Journal of Volcanology and Geothermal Research 138.1-2, pp. 77-110. DoI: $10.1016 / \mathrm{j}$. jvolgeores.2004.06.007.

Martín-Del Pozzo, A., T. González-Morán, R. E. M. Butron, and M. Reyes (2008). "Characterization of the recent ash emissions at Popocatepetl Volcano, Mexico". Journal of Volcanology and Geothermal Research 170.1-2, pp. 61-75. DOI: $10.1016 / \mathrm{j}$. jvolgeores.2007.09.004.

Martín-Del Pozzo, A. L., A. Rodríguez, and J. Portocarrero (2016). "Reconstructing 800 years of historical eruptive activity at Popocatépetl Volcano, Mexico". Bulletin of Volcanology 78.3. Dor: 10 1007 / s00445016-1010-y.

Mollo, S., M. Gaeta, C. Freda, T. Di Rocco, V. Misiti, and P. Scarlato (2010). "Carbonate assimilation in magmas: A reappraisal based on experimental petrology". Lithos 114.3-4, pp. 503-514. Dor: $10.1016 /$ j.lithos.2009.10.013.

Mooser, F. (1958). "Active Volcanoes of Mexico". Catalogue of the Active Volcanoes and Solfatara Fields of Central America. Ed. by F. Mooser, H. Meyer-Abich, and A. R. McBirney. Vol. 6. International Volcanological Association.

Newhall, C. G. and S. Self (1982). "The volcanic explosivity index (VEI) an estimate of explosive magnitude for historical volcanism". Journal of Geophysical Research 87.C2, p. 1231. DoI: 10.1029/ jc087ic02p01231.

Nielsen, R. L. and J. S. Beard (2000). "Magnetite-melt HFSE partitioning". Chemical Geology 164.1-2, pp. 21-34. Dor: 10.1016/s0009-2541 (99)00139-4.

Nixon, G. T. (1989). "The Geology of Iztaccíhuatl Volcano and Adjacent Areas of The Sierra Nevada and Valley of Mexico". Geological Society of America Special Papers. Ed. by G. T. Nixon. Geological Society of America, pp. 1-59. Dor: 10.1130/spe219-p1.

Nowell, G., P. Kempton, S. Noble, J. Fitton, A. Saunders, J. Mahoney, and R. Taylor (1998). "High precision Hf isotope measurements of MORB and OIB by thermal ionisation mass spectrometry: insights into the depleted mantle". Chemical Geology 149.3-4, pp. 211233. DoI: 10.1016/s0009-2541(98)00036-9.

Ortega-Gutierrez, F., J. Ruiz, and E. Centeno-Garcia (1995). "Oaxaquia, a Proterozoic microcontinent accreted to North America during the late Paleozoic". Geology 23.12, p. 1127. DoI: 10 . 1130/00917613(1995) 023<1127: oapmat>2.3. co;2.

Pankhurst, M. J., D. J. Morgan, T. Thordarson, and S. C. Loughlin (2018). "Magmatic crystal records in time, space, and process, causatively linked with volcanic unrest". Earth and Planetary Science Letters 493, pp. 231-241. DoI: 10.1016/ j . eps1.2018.04.025.

Panfil, M. S., T. W. Gardner, and K. G. Hirth (1999). "Late Holocene stratigraphy of the Tetimpa archaeological sites, northeast flank of Popocatépetl volcano, central Mexico". Geological Society of America Bulletin 111.2, pp. 204-218. DoI: 10 . 1130/0016-7606 (1999) 111<0204: lhsott>2.3.co;2.

Parfitt, E. A. and L. Wilson (1995). "Explosive volcanic eruptions-IX. The transition between Hawaiian-style lava fountaining and Strombolian explosive activity". Geophysical Journal International 121.1, pp. 226232. Dor: $10.1111 /$ j . 1365-246x. 1995. tb03523.x.

Petrone, C. M., L. Francalanci, R. W. Carlson, L. Ferrari, and S. Conticelli (2003). "Unusual coexistence of subduction-related and intraplate-type magmatism: $\mathrm{Sr}, \mathrm{Nd}$ and $\mathrm{Pb}$ isotope and trace element data from the magmatism of the San Pedro-Ceboruco graben (Nayarit, Mexico)". Chemical Geology 193.1-2, pp. 124. Dor: 10 . 1016/s0009-2541(02) 00229-2.

Pin, C. and J. S. Zalduegui (1997). "Sequential separation of light rare-earth elements, thorium and uranium by miniaturized extraction chromatography: Application to isotopic analyses of silicate rocks". Analytica Chimica Acta 339.1-2, pp. 79-89. DoI: 10 . 1016/s0003-2670 (96)00499-0.

Platz, T., S. J. Cronin, K. V. Cashman, R. B. Stewart, and I. E. Smith (2007). "Transition from effusive to explosive phases in andesite eruptions - A casestudy from the AD1655 eruption of Mt. Taranaki, New Zealand". Journal of Volcanology and Geothermal Research 161.1-2, pp. 15-34. DoI: $10.1016 / \mathrm{j}$. jvolgeores.2006.11.005.

Plunket, P. and G. Uruñuela (2008). "Mountain of sustenance, mountain of destruction: The prehispanic experience with Popocatépetl Volcano". Journal of Volcanology and Geothermal Research 170.1-2, pp. 111-120. Dor: $10.1016 / \mathrm{j}$. jvolgeores . 2007 . 09.012.

Price, R. C., J. A. Gamble, I. E. M. Smith, R. Maas, T. Waight, R. B. Stewart, and J. Woodhead (2012). "The Anatomy of an Andesite Volcano: a Time-Stratigraphic Study of Andesite Petrogenesis and Crustal Evolution at Ruapehu Volcano, New Zealand". Journal of Petrology 53.10, pp. 2139-2189. DoI: $10.1093 /$ petrology / egs050.

Ripepe, M., E. Marchetti, G. Ulivieri, A. Harris, J. Dehn, M. Burton, T. Caltabiano, and G. Salerno (2005). "Effusive to explosive transition during the 2003 eruption of Stromboli volcano". Geology 33.5, p. 341. DoI: $10.1130 / g 21173.1$.

Roberge, J., H. Delgado-Granados, and P. J. Wallace (2009). "Mafic magma recharge supplies high CO2 and $\mathrm{SO} 2$ gas fluxes from Popocatépetl volcano, Mexico". Geology 37.2, pp. 107-110. DOI: $10.1130 /$ g25242a. 1. 
Robin, C. and C. Boudal (1987). "A gigantic Bezymianny-type event at the beginning of modern volcan Popocatepetl". Journal of Volcanology and Geothermal Research 31.1-2, pp. 115-130. DoI: 10 . 1016/0377-0273 ( 87 ) 90009-6.

Roberts, S. J. and J. Ruiz (1989). "Geochemistry of exposed granulite facies terrains and lower crustal xenoliths in Mexico". Journal of Geophysical Research 94.B6, p. 7961. Dor: 10. 1029/ jb094 ib06p07961.

Robin, C. (1984). "Le Volcan Popocatepetl (Mexique): structure, evolution pétrologique et risques". Bulletin Volcanologique 47.1, pp. 1-23. Dor: 10 . 1007 / bf01960537.

Rudnick, R. and S. Gao (2003). "Composition of the Continental Crust". Treatise on Geochemistry. Elsevier, pp. 1-64. DoI: 10 . 1016/b0-08-043751-6/ 03016-4.

Ruiz, J., P. J. Patchett, and R. J. Arculus (1988). "Nd-Sr isotope composition of lower crustal xenoliths ? Evidence for the origin of mid-tertiary felsic volcanics in Mexico". Contributions to Mineralogy and Petrology 99.1, pp. 36-43. DoI: 10.1007/bf00399363.

Ruprecht, P. and O. Bachmann (2010). "Pre-eruptive reheating during magma mixing at Quizapu volcano and the implications for the explosiveness of silicic arc volcanoes". Geology 38.10, pp. 919-922. Dor: 10 . $1130 / \mathrm{g} 31110.1$.

Samaniego, P., H. Martin, C. Robin, and M. Monzier (2002). "Transition from calc-alkalic to adakitic magmatism at Cayambe volcano, Ecuador: Insights into slab melts and mantle wedge interactions". Geology 30.11, p. 967. Dor: 10 . 1130/0091-7613(2002) $030<0967$ : tfcata>2.0.co; 2 .

Schaaf, P., J. Stimac, C. Siebe, and J. L. Macías (2005). "Geochemical Evidence for Mantle Origin and Crustal Processes in Volcanic Rocks from Popocatépetl and Surrounding Monogenetic Volcanoes, Central Mexico". Journal of Petrology 46.6, pp. 1243-1282. Dor: 10.1093/petrology/egi015.

Schaaf, P., W. Heinrich, and T. Besch (1994). "Composition and $\mathrm{Sm}-\mathrm{Nd}$ isotopic data of the lower crust beneath San Luis Potosí, central Mexico: Evidence from a granulite-facies xenolith suite". Chemical Geology 118.1-4, pp. 63-84. Dor: 10 . 1016 / 0009 -2541 (94) 90170-8.

Siebe, C. and J. L. Macías (2006). "Volcanic hazards in the Mexico City metropolitan area from eruptions at Popocatépetl, Nevado de Toluca, and Jocotitlán stratovolcanoes and monogenetic scoria cones in the Sierra Chichinautzin Volcanic Field". Special Paper 402: Neogene-Quaternary Continental Margin Volcanism: A perspective from México. Geological Society of America, pp. 253-329. Dor: 10.1130/2004.vhitmc. sp402.

Siebe, C., S. Salinas, L. Arana-Salinas, J. L. Macías, J. Gardner, and R. Bonasia (2017). "The 23,500 y 14 C BP White Pumice Plinian eruption and associated debris avalanche and Tochimilco lava flow of
Popocatépetl volcano, México". Journal of Volcanology and Geothermal Research 333-334, pp. 66-95. Dor: 10.1016/ j . jvolgeores.2017.01.011.

Siebe, C., J. L. Macias, M. Abrams, S. Rodriguez, R. Castro, and H. Delgado (1995). "Quaternary explosive volcanism and pyroclastic deposits in east central Mexico: implications for future hazards". Guidebook of geological excursions: in conjunction with the Annual Meeting of the Geological Society of America, New Orleans, Louisiana, November 6-9, 1995, pp. 148.

Siebe, C., M. Abrams, J. L. Macías, and J. Obenholzner (1996). "Repeated volcanic disasters in Prehispanic time at Popocatépetl, central Mexico: Past key to the future?" Geology 24.5, p. 399. DoI: $10.1130 / 0091-$ 7613 ( 1996) 024<0399: rvdipt>2.3.co;2.

Siebe, C., P. Schaaf, and J. Urrutia-Fucugauchi (1999). "Mammoth bones embedded in a late Pleistocene lahar from Popocatépetl volcano, near Tocuila, central México". Geological Society of America Bulletin 111.10, pp. 1550-1562. DoI: 10 . $1130 / 0016$ - 7606(1999) $111<1550$ :mbeial>2. 3 . co; 2 .

Siebe, C. (2004). "Geochemistry, $\mathrm{Sr}-\mathrm{Nd}$ isotope composition, and tectonic setting of Holocene Pelado, Guespalapa and Chichinautzin scoria cones, south of Mexico City". Journal of Volcanology and Geothermal Research 130.3-4, pp. 197-226. Dor: 10 . 1016 / s0377 0273 ( 03 ) 00289-0.

Sosa-Ceballos, G., J. E. Gardner, C. Siebe, and J. L. Macías (2012). "A caldera-forming eruption 14, 10014Cyr BP at Popocatépetl volcano, México: Insights from eruption dynamics and magma mixing". Journal of Volcanology and Geothermal Research 213214, pp. 27-40. Dor: 10.1016/ j . jvolgeores . 2011. 11.001.

Sosa-Ceballos, G., J. E. Gardner, and J. C. Lassiter (2014). "Intermittent mixing processes occurring before Plinian eruptions of Popocatepetl volcano, Mexico: insights from textural-compositional variations in plagioclase and $\mathrm{Sr}-\mathrm{Nd}-\mathrm{Pb}$ isotopes". Contributions to Mineralogy and Petrology 167.2. DoI: 10.1007/ s00410-014-0966-x.

Sosa-Ceballos, G., J. L. Macías, F. García-Tenorio, P. Layer, P. Schaaf, G. Solís-Pichardo, and J. L. Arce (2015). "El Ventorrillo, a paleostructure of Popocatépetl volcano: insights from geochronology and geochemistry". Bulletin of Volcanology 77.10. DoI: 10. 1007/s00445-015-0975-2.

Straub, S. M. and A. L. Martín-Del Pozzo (2001). "The significance of phenocryst diversity in tephra from recent eruptions at Popocatepetl volcano (central Mexico)". Contributions to Mineralogy and Petrology 140.4, pp. 487-510. Dor: 10. 1007 / pl00007675.

Straub, S. M., A. B. LaGatta, A. L. Martín-Del Pozzo, and C. H. Langmuir (2008). "Evidence from high$\mathrm{Ni}$ olivines for a hybridized peridotite/pyroxenite source for orogenic andesites from the central Mex- 
ican Volcanic Belt". Geochemistry, Geophysics, Geosystems 9.3. DOI: $10.1029 / 2007 \mathrm{gc} 001583$.

Straub, S. M., A. Gomez-Tuena, F. M. Stuart, G. F. Zellmer, R. Espinasa-Pereña, Y. Cai, and Y. Iizuka (2011). "Formation of hybrid arc andesites beneath thick continental crust". Earth and Planetary Science Letters 303.3-4, pp. 337-347. Dor: 10.1016/ j . epsl . 2011.01 .013$.

Straub, S. M., A. Gómez-Tuena, G. F. Zellmer, R. Espinasa-Pereña, F. M. Stuart, Y. Cai, C. H. Langmuir, A. L. Martín-Del Pozzo, and G. T. Mesko (2013). "The Processes of Melt Differentiation in Arc Volcanic Rocks: Insights from OIB-type Arc Magmas in the Central Mexican Volcanic Belt". Journal of Petrology 54.4, pp. 665-701. Dor: $10.1093 /$ petrology / egs081.

Straub, S. M., G. F. Zellmer, A. Gómez-Tuena, R. Espinasa-Pereña, A. L. Martín-Del Pozzo, F. M. Stuart, and C. H. Langmuir (2014). "A genetic link between silicic slab components and calc-alkaline arc volcanism in central Mexico". Orogenic Andesites and Crustal Growth. Ed. by A. Gómez-Tuena, S. M. Straub, and G. F. Zellmer. Vol. 385. 1. Geological Society of London, pp. 31-64. Dor: 10.1144/sp385. 14.

Straub, S. M., A. Gómez-Tuena, I. N. Bindeman, L. L. Bolge, P. A. Brandl, R. Espinasa-Pereña, L. Solari, F. M. Stuart, P. Vannucchi, and G. F. Zellmer (2015). "Crustal recycling by subduction erosion in the central Mexican Volcanic Belt". Geochimica et Cosmochimica Acta 166, pp. 29-52. DoI: $10.1016 /$ j . gca.2015.06.001.

Strekopytov, S. and A. Dubinin (1997). "Determination of Zr, Hf, Mo, W, and Th in Standard Samples of Oceanic Sediments by the Mass Spectrometry with Induction-Connected Plasma". Zhurnal Analiticheskoi Khimii 168, pp. 279-281.

Sun, S.-s. and W. F. McDonough (1989). "Chemical and isotopic systematics of oceanic basalts: implications for mantle composition and processes". Geological Society, London, Special Publications 42.1, pp. 313345. Dor: 10.1144/gsl.sp.1989.042.01.19.

Tanaka, T. et al. (2000). "JNdi-1: a neodymium isotopic reference in consistency with LaJolla neodymium". Chemical Geology 168.3-4, pp. 279-281. DoI: 10 . 1016/s0009-2541(00)00198-4.

Tepley, F. J., S. D. Silva, and G. Salas (2013). "Magma Dynamics and Petrological Evolution Leading to the VEI 52000 bp Eruption of El Misti Volcano, Southern Peru". Journal of Petrology 54.10, pp. 2033-2065. Dor: 10. 1093/petrology/egt040.

Thirlwall, M. (1991). "Long-term reproducibility of multicollector Sr and Nd isotope ratio analysis". Chemical Geology: Isotope Geoscience section 94.2, pp. 85-104. Dor: 10.1016/0168-9622 (91) 90002-e.

Torres-Alvarado, I. S., A. D. Smith, and J. CastilloRomán (2011). "Sr, $\mathrm{Nd}$ and $\mathrm{Pb}$ isotopic and geochemical constraints for the origin of magmas in Popocatépetl volcano (central Mexico) and their re- lationship with the adjacent volcanic fields". International Geology Review 53.1, pp. 84-115. DoI: 10 . 1080/00206810902906738.

Tormey, D. R., F. A. Frey, and L. Lopez-Escobar (1995). "Geochemistry of the Active AzufrePlanchon-Peteroa Volcanic Complex, Chile ( 35 15'S): Evidence for Multiple Sources and Processes in a Cordilleran Arc Magmatic System". Journal of Petrology 36.2, pp. 265-298. Dor: 10.1093/petrology/36. 2.265.

Tourrette, T., D. Burnett, and C. R. Bacon (1991). "Uranium and minor-element partitioning in Fe-Ti oxides and zircon from partially melted granodiorite, Crater Lake, Oregon". Geochimica et Cosmochimica Acta 55.2, pp. 457-469. Dor: 10 . 1016/0016-7037 (91) 90004-o. Varley, N. and M. Armienta (2001). "The absence of diffuse degassing at Popocatépetl volcano, Mexico". Chemical Geology 177.1-2, pp. 157-173. DoI: 10 . 1016/s0009-2541(00)00389-2.

Vervoort, J. D., P. Patchett, F. Albarède, J. Blichert-Toft, R. Rudnick, and H. Downes (2000). "Hf-Nd isotopic evolution of the lower crust". Earth and Planetary Science Letters 181.1-2, pp. 115-129. DOI: 10.1016/ s0012-821x (00) 00170-9.

Vervoort, J. D., T. Plank, and J. Prytulak (2011). "The Hf-Nd isotopic composition of marine sediments". Geochimica et Cosmochimica Acta 75.20, pp. 59035926. DoI: 10.1016/ j . gca.2011.07.046.

Verma, S. P. (1999). "Geochemistry of evolved magmas and their relationship to subduction-unrelated mafic volcanism at the volcanic front of the central Mexican Volcanic Belt". Journal of Volcanology and Geothermal Research 93.1-2, pp. 151-171. DOI: 10 . 1016/s03770273 (99) 00086- 4.

Wallace, P. J. and I. S. E. Carmichael (1999). "Quaternary volcanism near the Valley of Mexico: implications for subduction zone magmatism and the effects of crustal thickness variations on primitive magma compositions". Contributions to Mineralogy and Petrology 135.4, pp. 291-314. Dor: 10 . 1007 / s004100050513.

Weis, D. et al. (2006). "High-precision isotopic characterization of USGS reference materials by TIMS and MC-ICP-MS". Geochemistry, Geophysics, Geosystems 7.8. DoI: $10.1029 / 2006 g c 001283$.

Weis, D., B. Kieffer, D. Hanano, I. N. Silva, J. Barling, W. Pretorius, C. Maerschalk, and N. Mattielli (2007). "Hf isotope compositions of U.S. Geological Survey reference materials". Geochemistry, Geophysics, Geosystems 8.6. Dor: 10.1029/2006gc001473.

Weis, D. and F. Frey (1991). "Isotope Geochemistry of Ninetyeast Ridge Basement Basalts: Sr, Nd, and $\mathrm{Pb}$ Evidence for Involvement of the Kerguelen Hot Spot". Proceedings of the Ocean Drilling Program 121, pp. 591-610. Dor: 10.2973/odp . proc. sr. 121.170. 1991.

Weis, D. and F. A. Frey (1996). "Role of the Kerguelen Plume in generating the eastern Indian Ocean 
seafloor". Journal of Geophysical Research: Solid Earth 101.B6, pp. 13831-13849. Dor: 10. 1029/96 jb00410.

Wilson, L., R. S. J. Sparks, and G. P. L. Walker (1980). "Explosive volcanic eruptions - IV. The control of magma properties and conduit geometry on eruption column behaviour". Geophysical Journal International 63.1, pp. 117-148. DoI: 10.1111 / j . $1365-246 x$. 1980. tb02613.x.

Witter, J. B., V. C. Kress, and C. G. Newhall (2005). "Volcán Popocatépetl, Mexico. Petrology, Magma Mixing, and Immediate Sources of Volatiles for the 1994-Present Eruption". Journal of Petrology 46.11, pp. 2337-2366. DoI: 10.1093/petrology/egi 058.

Woods, A. W. and T. Koyaguchi (1994). "Transitions between explosive and effusive eruptions of silicic magmas". Nature 370.6491, pp. 641-644. DoI: 10.1038/ $370641 \mathrm{a} 0$.

\section{A Appendix 1: Analytical Methods}

\section{A.1 Major and trace element analysis}

Powdered bulk rock samples were analysed for major element compositions at Activation Laboratories Ltd., Ancaster, Canada, using X-ray Fluorescence (XRF) analysis, including United States Geological Survey (USGS) reference materials processed as unknowns (see Supplementary Table S1.2).

Trace element concentrations were determined on an Agilent 8800 Triple Quadrupole inductively coupled plasma mass spectrometer (ICP-MS) at the Open University, Milton Keynes, and on an Agilent 7700x ICPMS at the Natural History Museum, London.

Samples for trace element analysis at the Open University were digested at the MAGIC laboratories at Imperial College London. Approximately $50 \mathrm{mg}$ of whole rock sample powders were weighed into Savillex PFA beakers in a 2:1 mixture of concentrated distilled HF and $\mathrm{HNO}_{3}$. Samples were ultrasonicated for $20 \mathrm{~min}-$ utes and digested on a hotplate at $130^{\circ} \mathrm{C}$ for 3 days. After evaporation to incipient dryness, samples were converted to chlorides in two steps of dissolution in distilled $6 \mathrm{M} \mathrm{HCl}$ and subsequent evaporation. Samples were then taken up in distilled concentrated $\mathrm{HNO}_{3}$ and evaporated at $180^{\circ} \mathrm{C}$ at least two times, ensuring the breakdown of any remaining fluorides. For analysis on an Agilent 8800 Triple Quadrupole ICP-MS at the Open University, 1000-fold dilutions in $2 \%$ distilled concentrated $\mathrm{HNO}_{3}$ were prepared. Elemental concentrations were determined with three modes of analysis. Measurements were performed both with no gas and with $\mathrm{He}$ gas in the collision cell. Helium gas reduces transmission and sensitivity, but is effective at minimising molecular interferences. Rare earth elements were measured by $\mathrm{O}_{2}$ mass-shift mode to avoid isobaric interferences. To monitor instrumental drift, samples were run with an internal (Be, Rh, In, Tm, Bi) standard. Measurements were calibrated with five international United States Geological Survey (USGS) reference materials relevant to the compositional range at the PVC, i.e. BIR-1, W-2, DNC-1, BHVO-2 and AGV-1. Procedural blanks were below the detection limit for all reported elements. Repeat measurements of USGS reference material BCR-2 indicates a repeatability of $<7$ $\% 2 \mathrm{SD}$ and a relative deviation from recommended values of $<5 \%$ for most elements (see Supplementary Data 1(Table S1.3)). Repeatability and instrument drift was further monitored with duplicate measurements of BCR-2 and the same unknown sample every five unknowns throughout measurement sessions.

For trace element analysis on an Agilent 7700x ICPMS at the Natural History Museum, London, approximately $100 \mathrm{mg}$ of sample powder were digested with 1 $\mathrm{mL} \mathrm{HNO}_{3}$ and $4 \mathrm{~mL} \mathrm{HF}$ overnight at $100^{\circ} \mathrm{C}$ in closed, screw-top Teflon beakers. The vessels were opened and the contents evaporated to dryness at $150{ }^{\circ} \mathrm{C}$. The residue was then re-treated with $1 \mathrm{~mL} \mathrm{HClO}_{4}$ and evaporated to dryness, then re-dissolved in $2 \mathrm{~mL} \mathrm{HNO}_{3}$ and $0.2 \mathrm{~mL} \mathrm{H}_{2} \mathrm{O}_{2}$ and made up to $50 \mathrm{~mL}$ with $\mathrm{MQ}$ water. All acids used were of trace element analysis grade (Romil-SpA). Most elements (apart from Ga, Nb, Sn, $\mathrm{Ta}, \mathrm{Tl}, \mathrm{Pb}$ and $\mathrm{Th}$ ) were determined with $5 \mathrm{~mL} / \mathrm{min}$ $\mathrm{He}$ in the collision-reaction cell to minimise molecular interferences. Additionally, interferences from molecular species and doubly charge ions affecting ${ }^{71} \mathrm{Ga}$, ${ }^{151} \mathrm{Eu},{ }^{157} \mathrm{Gd},{ }^{159} \mathrm{~Tb},{ }^{178} \mathrm{Hf}$ and ${ }^{181} \mathrm{Ta}$ were mathematically corrected [Strekopytov and Dubinin 1997; Ferrat et al. 2012]. The concentrations in procedural blanks (one per ten digested samples) were below the limits of quantification for all elements except $\mathrm{Cr}, \mathrm{Zn}, \mathrm{Ba}$ and $\mathrm{Pb}$, for which the maximum possible relative contribution of the blanks to the total content in the sample was less than $1 \%, 6 \%, 0.4 \%$ and $1.5 \%$, respectively. Accuracy of the method was checked by analysis of certified reference materials JLs-1 (Limestone, Geological Survey of Japan) and BCR-2 (see Supplementary Table S1.3).

\section{A.2 $\mathrm{Sr}-\mathrm{Nd}-\mathrm{Hf}$ isotope analysis}

Strontium and $\mathrm{Nd}$ isotopic compositions of all samples, as well as Hf isotopic compositions on a representative subset were determined at the MAGIC laboratories at Imperial College London. Approximately 50 mg of whole rock sample powders were dissolved in a 3:1 mixture of distilled concentrated HF and concentrated $\mathrm{HNO}_{3}$, and ultrasonicated for 20 minutes. Sample solutions were digested on a hotplate at $120^{\circ} \mathrm{C}$ for at least 24 hours, then evaporated to incipient dryness. Samples were re-dissolved in $3 \mathrm{~mL}$ distilled concentrated $\mathrm{HNO}_{3}$ for 24 hours at $140{ }^{\circ} \mathrm{C}$ and evaporated at $180^{\circ} \mathrm{C}$. Samples were re-dissolved in $1 \mathrm{~mL}$ of distilled $6 \mathrm{M} \mathrm{HCl}$ and evaporated at $120^{\circ} \mathrm{C}$. Finally, the sample residues were dissolved in $1 \mathrm{~mL}$ of $1 \mathrm{M} \mathrm{HCl}$ for 24 hours at $120^{\circ} \mathrm{C}$.

Samples were petrographically fresh (i.e. mineral 
phases lacked obvious alteration), however to test potential effects of secondary phases related to weathering on $\mathrm{Sr}$ and $\mathrm{Nd}$ isotopic compositions, two lava samples and a pumice sample with the highest loss on ignition value were leached according to the procedure described in Weis and Frey [1991] and Weis and Frey [1996] before digestion. Sample powders were suspended in $10 \mathrm{~mL}$ of distilled $6 \mathrm{M} \mathrm{HCl}$, the solid solution was ultrasonicated for 20 minutes and the supernatant then decanted. This procedure was repeated until the supernatant was clear. A comparison of isotopic compositions obtained from leached and unleached digestions of the same samples shows no systematic or significant differences in $\mathrm{Sr}-\mathrm{Nd}$ isotope composition, indicating that alteration and secondary phases do not bias $\mathrm{Sr}$ and $\mathrm{Nd}$ isotope characteristics (Figure A1). Stron-

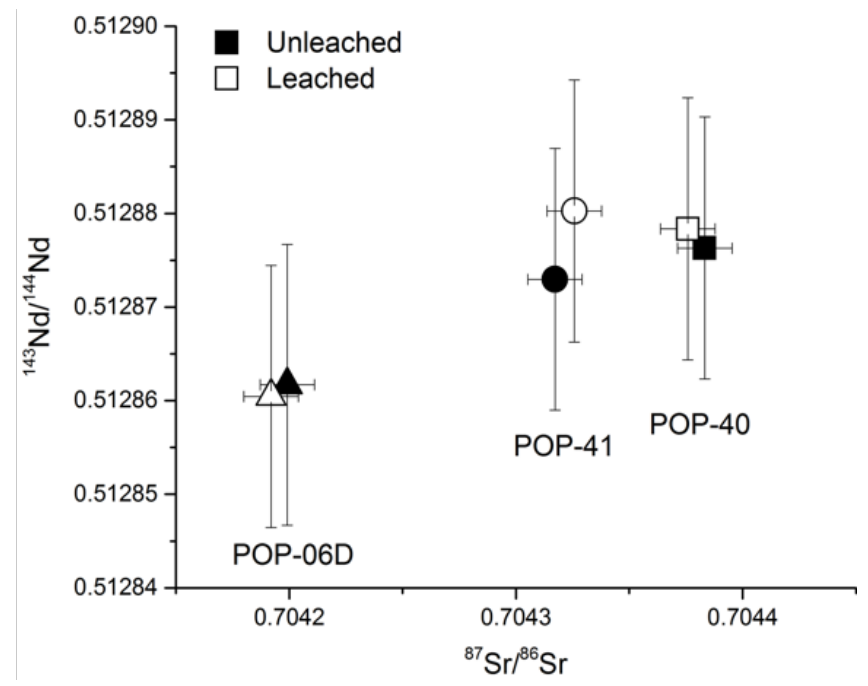

Figure A1: Sr-Nd isotope ratios of leached and unleached digestions of a pumice (POP-06D) and two lavas. Results are indistinguishable within uncertainties. Error bars are 2 SE for Sr isotopic ratios, and 2 SD for $\mathrm{Nd}$ isotopic ratios.

tium and $\mathrm{Nd}$ were separated from the same digestions in three chromatographic steps. The first column achieved a pre-separation of REE and Sr using $2 \mathrm{~mL}$ Bio-rad columns containing $1.4 \mathrm{~mL}$ Bio-rad AG 50Wx8 200-400 mesh cation exchange resin. Samples were loaded in $1 \mathrm{~mL} 1 \mathrm{M} \mathrm{HCl}$. Iron and other matrix elements were eluted with $3 \mathrm{~mL} 3 \mathrm{M} \mathrm{HCl}$, before collecting $\mathrm{Sr}$ in $4 \mathrm{~mL} 3 \mathrm{M} \mathrm{HCl}$ and $0.5 \mathrm{~mL} 6 \mathrm{M} \mathrm{HCl}$. Rare earth elements were then collected with $6.5 \mathrm{~mL} 6 \mathrm{M}$ $\mathrm{HCl}$. The Sr fraction from the cation exchange column was then evaporated, converted to nitrates and redissolved in $300 \mu \mathrm{L} 3 \mathrm{M} \mathrm{HNO}_{3}$. Further Sr purification was achieved using the Sr-selective Eichrom Sr resin (100-150 $\mu \mathrm{m})$ after Horwitz et al. [1992]. The REE fraction from the cation exchange column was evaporated and re-dissolved in $200 \mu \mathrm{L} 0.192 \mathrm{M} \mathrm{HCl}$. Neodymium was separated from the other REE using Eichrom Ln resin $(100-150 \mu \mathrm{m})$ and a procedure modified from Pin and Zalduegui [1997]. Total procedural blanks pro- cessed with each set of chemistry were $<400 \mathrm{pg}$ for $\mathrm{Sr}$ and $<20 \mathrm{pg}$ for $\mathrm{Nd}$. The USGS BCR- 2 reference material was digested and processed as an unknown with each set of samples.

Strontium isotopic compositions were analysed on a Thermo Finnigan Triton thermal ionization mass spectrometer. Between 300 and $1000 \mathrm{ng}$ of sample were pipetted on zone-refined Re filaments, and run in 12 blocks of 15 cycles with an integration time of 16.777 seconds per cycle. To rule out effects of gain calibration errors on the accuracy of the results, amplifiers were rotated between each block (Virtual Amplifier). Rubidium interference was monitored and corrected online using ${ }^{87} \mathrm{Rb} /{ }^{85} \mathrm{Rb}=0.3856$, and $\mathrm{Sr}$ isotope ratios were corrected for mass-dependent fractionation using the exponential law and ${ }^{86} \mathrm{Sr} /{ }^{88} \mathrm{Sr}=0.1194$. Strontium data is reported normalised to the accepted value of Sr metal standard NIST SRM 987 of ${ }^{87} \mathrm{Sr} /{ }^{86} \mathrm{Sr}=0.710248$ [Thirlwall 1991]. The instrumental precision within a single sample run is $\leq 6 \mathrm{ppm} 2 \mathrm{SE}$ (Table 1 ). Aliquots of USGS reference material BCR-2 digested with the samples and measured during the analysis period yield an average of ${ }^{87} \mathrm{Sr} /{ }^{86} \mathrm{Sr}=0.705008 \pm 7$ (2 SD; $n=14$; see Supplementary Data 1: Table S1.4), in agreement with the recommended value of ${ }^{87} \mathrm{Sr} /{ }^{86} \mathrm{Sr}=0.705013 \pm 10$ [Weis et al. 2006]. Repeatability of the method was further confirmed by replicate digestions of ten samples, which deviate by $\leq 7$ ppm.

Neodymium isotopic compositions were analysed on a $\mathrm{Nu}$ Instruments $\mathrm{Nu}$ Plasma HR multi-collector ICPMS. Samples were introduced using a Nu DSN-100 Desolvation Nebuliser System as $50 \mathrm{ppb} \mathrm{Nd}$ solutions in $0.1 \mathrm{M}$ distilled $\mathrm{HNO}_{3}$. Data was acquired in three blocks of 20 cycles, and ratios were corrected online for mass bias with the exponential law and using ${ }^{146} \mathrm{Nd} /{ }^{144} \mathrm{Nd}=0.7219$. Potential Sm and Ce interferences were corrected using ${ }^{144} \mathrm{Sm} /{ }^{147} \mathrm{Sm}=0.20498$, ${ }^{148} \mathrm{Sm} /{ }^{147} \mathrm{Sm}=0.74970,{ }^{150} \mathrm{Sm} /{ }^{147} \mathrm{Sm}=0.49219$, and ${ }^{142} \mathrm{Ce} /{ }^{140} \mathrm{Ce}=0.12565$, respectively. ${ }^{143} \mathrm{Nd} /{ }^{144} \mathrm{Nd}$ ratios are reported normalised to the accepted value of neodymium standard JNdi of ${ }^{143} \mathrm{Nd} /{ }^{144} \mathrm{Nd}=0.512115$ [Tanaka et al. 2000]. The instrumental precision within a single $\mathrm{Nd}$ sample run is $\leq 12 \mathrm{ppm} 2 \mathrm{SE}$. Reported ${ }^{143} \mathrm{Nd} /{ }^{144} \mathrm{Nd}$ ratios are averages of multiple sample measurements, and reported 2 SD are either the standard deviations of these averages, or of BCR-2 averages analysed with the samples, whichever is larger. BCR-2 aliquots analysed during the analysis period yielded an average value of ${ }^{143} \mathrm{Nd} /{ }^{144} \mathrm{Nd}=0.512637 \pm 11(2 \mathrm{SD} ; n$ = 49; see Supplementary Table S1.4), in agreement with the accepted value of $0.512638 \pm 11$ [Weis et al. 2006].

A subset of 21 samples covering the complete period of volcanism examined in this study was analysed for Hf isotopic compositions. To ensure a complete digestion including potential zircon crystals, bomb digestions were conducted. Approximately $50 \mathrm{mg}$ of sample powder were weighed into hexagonal screw-top Teflon bombs and a 2:1 mixture of concentrated distilled HF 
and $\mathrm{HNO}_{3}$ added. The bombs were then sealed and placed in an oven at $160^{\circ} \mathrm{C}$ for five days. This initial treatment replaced the first digestion step described for Sr-Nd. After oven digestion, subsequent treatment of the samples was as described for Sr-Nd digestions. Hafnium isolation was achieved in a two-stage column chemistry following the procedure of Bast et al. [2015]. Hafnium isotopic compositions were analysed on a $\mathrm{Nu}$ Instruments Nu Plasma HR multiple collector ICP-MS. Samples were introduced as $30 \mathrm{ppb}$ Hf solutions in distilled $0.5 \mathrm{M} \mathrm{HNO}_{3}-0.3 \mathrm{M} \mathrm{HF}$ and analysed in one block of 60 cycles. Wash time between each sample was 2 $\times 160$ seconds to ensure complete Hf washout back to background levels between samples and standards. Mass fractionation was corrected online using the exponential law and ${ }^{179} \mathrm{Hf} /{ }^{177} \mathrm{Hf}=0.7325$, and potential mass interferences for $\mathrm{Yb}$ and $\mathrm{W}$ were monitored and corrected using natural abundances ratios ${ }^{176} \mathrm{Yb} /{ }^{172} \mathrm{Yb}$ $=0.58341,{ }^{174} \mathrm{Yb} /{ }^{172} \mathrm{Yb}=1.45990$ and ${ }^{180} \mathrm{~W} /{ }^{182} \mathrm{~W}=$ 0.00450. Measured ${ }^{176} \mathrm{Hf} /{ }^{177} \mathrm{Hf}$ ratios were corrected for the accepted value for Hf standard JMC-475 of ${ }^{176} \mathrm{Hf} /{ }^{177} \mathrm{Hf}=0.282160$ [Nowell et al. 1998]. The instrumental precision within a single $\mathrm{Hf}$ sample run is $\leq 6 \mathrm{ppm} 2$ SE (Table 1). Two separate BCR-2 digestions were analysed, yielding an average of ${ }^{176} \mathrm{Hf} /{ }^{177} \mathrm{Hf}=$ $0.282866 \pm 7$ (2 SD; $n=5$; see Supplementary Data 1: Table S1.4), in agreement with the recommended value of ${ }^{176} \mathrm{Hf} /{ }^{177} \mathrm{Hf}=0.282870 \pm 8$ (2 SD; Weis et al. [2007]).

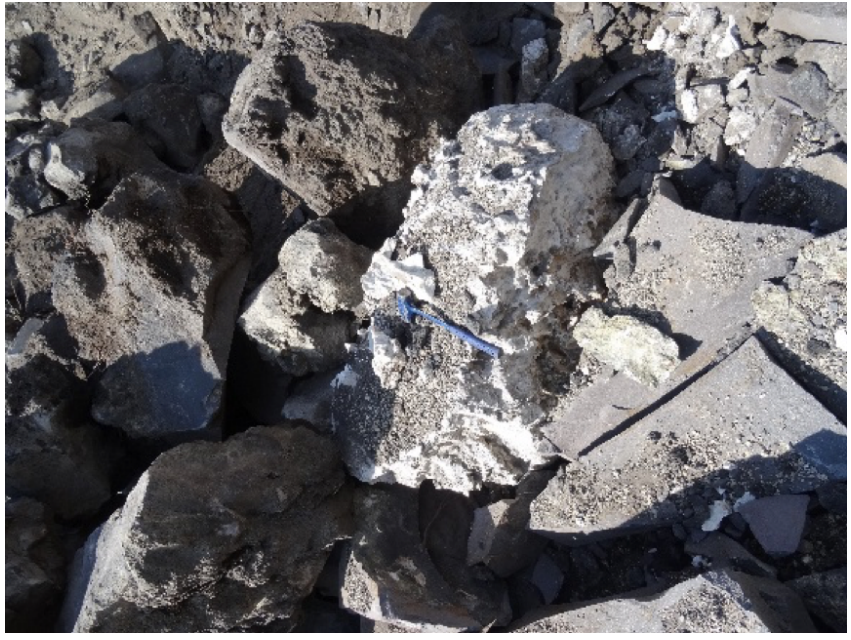

Figure B.2: Photograph of $\sim 1 \times 2 \mathrm{~m}$ anhydrite xenolith POP-97-m2 found within a quarry of the Nealticán lava. The exterior of the anhydrite boulder looks rounded and corroded, whereas its interior is very fresh and appears to be unaffected by interaction with the magma.

\section{B Appendix 2: Field evidence for magma MINGLING AND XENOLITHS}
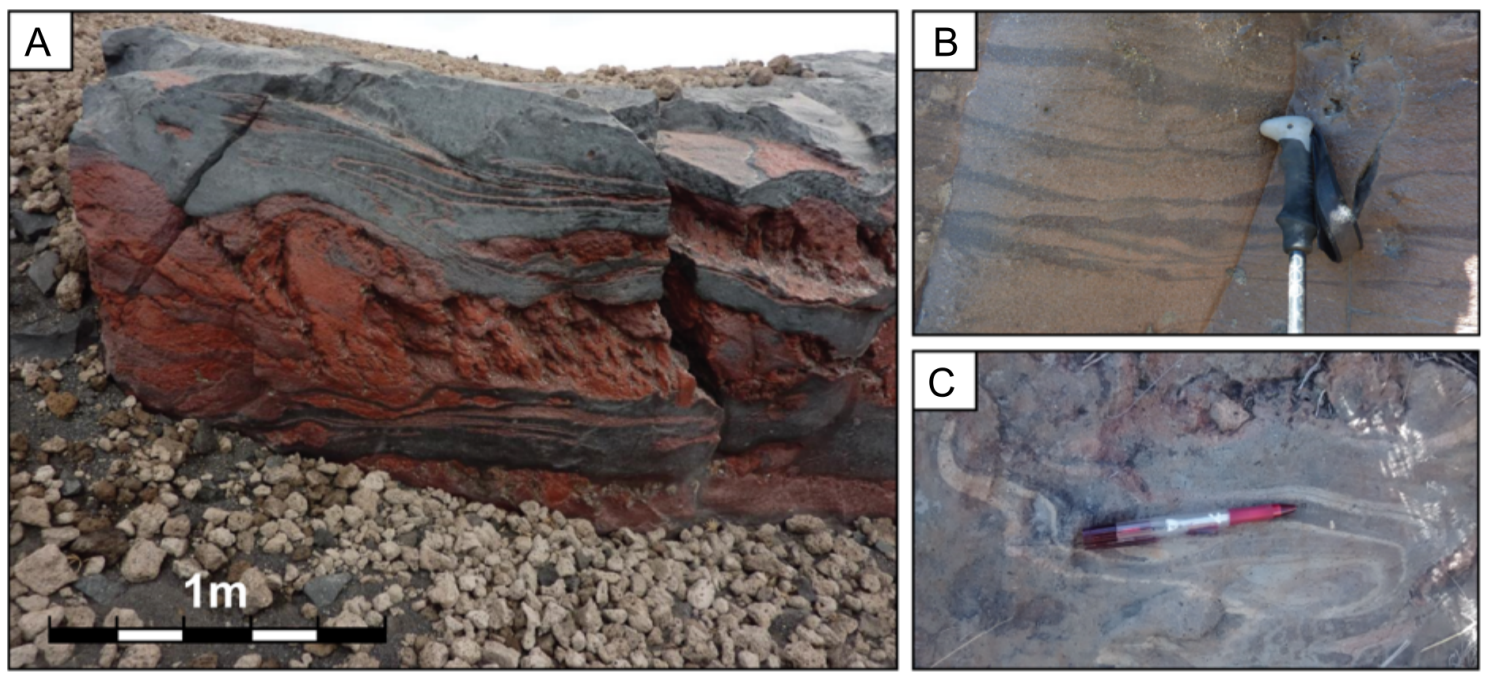

Figure B.1: Mingling textures in PVC lavas on various scales. [A] Proximal Ventorrillo lava. [B] Chipiquixtle lava. [C] San Pedro lava. Photograph of mingled lava belonging to the proximal Ventorrillo cone. Photographs [A] and [B] by C. M. Petrone. 